\title{
Synthesis, characterization and biological evaluation of novel 2,2'-((1,2-diphenylethane-1,2-diylidene)bis(azanylylidene)) bis(pyridin-3-ol)and metal complexes: molecular docking and in silico ADMET profile
}

\author{
S. Syed Ali Fathima ${ }^{1}$ - M. Mohamed Sahul Meeran ${ }^{2}$ - E. R. Nagarajan ${ }^{1}$
}

Received: 31 May 2019 / Accepted: 2 September 2019 / Published online: 16 October 2019

(C) Springer Science+Business Media, LLC, part of Springer Nature 2019

\begin{abstract}
A novel series of bio vital Schiff base ligand and transition metal complexes was prepared from benzil, 2-amino-3-hydroxy pyridine and metal chlorides. The synthesized compounds were characterized by physicochemical measurements like elemental analysis, magnetic susceptibility, molar conductance and multispectral analysis like Fourier transform, electronic absorption, nuclear magnetic resonance, electron paramagnetic resonance, ESI-mass spectroscopy, XRD and scanning electron microscopy. Based on the spectral results, the synthesized compounds are in crystalline nature and copper complex has square planar geometry. Conversely, cobalt, nickel and zinc complexes have tetrahedral geometry. Furthermore, the biological potential of the synthesized compounds is analysed by DNA binding and cleavage analysis and antimicrobial, anticancer, apoptosis and antioxidant inspections. The DNA binding analysis was performed using UV absorption titration and hydrodynamic experiments, which unveiled that the prepared compounds could be interconnected with calf thymus DNA by the way of intercalative mode. The mode of intercalation is further supported by docking investigations with nucleic acid and Bowman-Birk inhibitor. The DNA cleaving analysis implied that $\mathrm{Cu}$ (II) complex has eminent cleaving ability to split up the pUC18 DNA with an oxidising agent. Additionally, the anti-pathogenic screening studies explained that the complexes have antimicrobial skill against selected microbes. The anti-carcinogenic talent of the compounds is scrutinized on human cancer cell lines, which revealed that the prepared compounds possess good anticancer proficiency. During Hoechst staining analysis, the synthesized compounds have undergone the morphological moderations and succeeding cell death. The free radical scavenging investigations display that the metal complexes hold the suited talent to hunt the $\mathrm{OH}$ radical effectively. The prediction of in silico ADMET belongings found out that synthesized compounds acquire substantial drug-likeness characters based on Lipinski's rules.
\end{abstract}

Highlights

- Synthesis and characterization of the novel bio-vital pyridine-based

compounds.

- Compounds possess substantial DNA binding, cleavage, antimicrobial, anticancer and antioxidant proficiency.

- Appreciable morphological changes and cell death occur upon apoptosis.

- Prediction of the drug-likeness character of the compounds.

- Doping of the synthesized compounds with DNA and Bowman-Birk inhibitor using AutoDock Vina software.

Electronic supplementary material The online version of this article (https://doi.org/10.1007/s11224-019-01425-7) contains supplementary material, which is available to authorized users.

E. R. Nagarajan nagarajanklu@gmail.com
2 Nesma Trading Co. Limited, Al-Khobar 31952, Kingdom of Saudi Arabia

1 International Research Centre, Department of Chemistry,

Kalasalingam Academy of Research and Education,

Krishnankoil, Tamil Nadu 626126, India 
Keywords Transition metal complexes $\cdot$ DNA binding $\cdot$ Docking $\cdot$ Anticancer $\cdot$ Antioxidant $\cdot$ In silico ADMET

\section{Introduction}

The expansion change in the material chemistry section has focused attention on metal complexes because they have realized that they are biologically useful for making compounds [1-3]. A broad series of biological actions namely antimicrobial, anti-proliferative and antioxidant performances are produced by the $\mathrm{N}$ and $\mathrm{O}$ carrying metal complexes [4]. In all types of biological activity, metal acts as a unique role for establishing novel based therapeutic drugs [5].

Generally, small compounds that are connected and interacting with DNA increase their biological ability $[6,7]$. Transition metal complexes are a group of compounds containing metal centre and heteroatom such as $\mathrm{N}, \mathrm{O}$ and $\mathrm{S}$, which occupy a position to interact with nucleic acid by producing $\mathrm{H}-$ bond [8]. This is an important phenomenon for creating novelbased therapeutic drugs. Typically, the pharmacologically active compounds enhance their cleavage activity and thereby enable a skilled anti-proliferative agent for different types of tumours [9].

Benzil is a strong inhibitor of human carboxylesterase enzymes involved in the hydrolysis of carboxylic esters and several medicinally utilized capsules [10]. Nowadays, pyridine-based compounds are used in structurally simple drugs, for example, isoniazid, ethionamide, bupicomide and sulpha pyridine (dihydropteroate synthetase inhibitor), which are used in pneumococcal pneumonia and minimized the death rates by 25 to $6 \%$ [11-17]. Schiff base ligands obtained from pyridine moiety and their copper compounds are used in chemotherapeutic drugs [18]. Particularly, 2-amino-3hydroxy pyridine plays a specific role in anti-inflammatory medicines [19].

As part of our research investigation, pyridine-based Schiff base metal complexes were prepared by benzil, 2aminopyridin-3-ol and metal chlorides. Moreover, the prepared compounds are characterized by spectral analysis to ensure the geometry of the metal complexes. From the biological analysis, the synthesized compounds have been proved to be excellent antimicrobial, antioxidant and anti-carcinogenic agents.

\section{Experimental procedure}

\section{Synthesis of Schiff base ligand}

For the synthesis of Schiff base ligand, 2-amino-3-hydroxy pyridine $(0.220 \mathrm{~g}, 2 \mathrm{mmol})$ and benzil $(0.2102 \mathrm{~g}, 1 \mathrm{mmol})$ are dissolved in ethanol separately and mixed together after adding three drops of glacial acetic acid and $\mathrm{K}_{2} \mathrm{CO}_{3}$ and reflux for $4 \mathrm{~h}$. The yellow-colour crystalline product was obtained. The resulting product was washed with ethanol, filtered and recrystallized from ethanol. The procured crystalline product was dried over anhydrous $\mathrm{CaCl}_{2}$ under vacuum condition. The mechanism of Schiff base ligand is depicted in Scheme 1.

Yield: $89 \%$. M.F. $\left(\mathrm{C}_{24} \mathrm{H}_{18} \mathrm{~N}_{4} \mathrm{O}_{2}\right)$; colour: yellow; M.P: $180{ }^{\circ} \mathrm{C}$; anal. cal. for $\left[\mathrm{C}_{24} \mathrm{H}_{18} \mathrm{~N}_{4} \mathrm{O}_{2}\right]: \mathrm{C} 72.08 \%, \mathrm{H} 4.65 \%$, N $14.10 \%$, found: C $72.01 \%, \mathrm{H} 4.44 \%, \mathrm{~N} 14.08 \% ; \lambda_{\max } \mathrm{cm}^{-1}$ in DMSO $37037\left(\pi \rightarrow \pi^{*}\right)$ 31,152 $\left(\mathrm{n} \rightarrow \pi^{*}\right)$ FT-IR (KBr disc $\left.\mathrm{cm}^{-1}\right): 1592 v(-\mathrm{C}=\mathrm{N}), 3437 v(-\mathrm{OH}) ;{ }^{1} \mathrm{H}$ NMR (DMSO-d $\left.\mathrm{d}_{6}\right)$ (ठ): (aromatic) 7.33-8.27 (m), (-OH) $9.63(\mathrm{~s}),{ }^{13} \mathrm{C}$ NMR

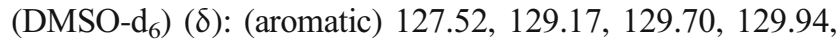
$(-\mathrm{C}=\mathrm{N})$ 158.19, $(-\mathrm{C}-\mathrm{OH})$ 165.16; ESI-MS: $395(\mathrm{M}+1)$.

\section{Synthesis of metal complexes}

To prepare the Schiff base metal complexes, Schiff base ligand $(0.3940 \mathrm{~g}, 1 \mathrm{mmol})$ and the metal chloride salt $(1 \mathrm{mmol})$ were dissolved in ethanol and mixed together. The resultant mixture was allowed to sonicate for $4 \mathrm{~h}$. Then, the obtained mixture was gradually stirred with reflux for $12 \mathrm{~h}$. The obtained crystalline product was washed with ethanol and then recrystallized. The final product was dried over anhydrous $\mathrm{CaCl}_{2}$ under vacuum. The scheme of metal complex is displayed in Scheme 2.

[CuL]: yield: $78 \%$; colour: brown; M.P: $285{ }^{\circ} \mathrm{C}$; M. Wt: 455; anal. cal. for $\left[\mathrm{CuC}_{24} \mathrm{H}_{16} \mathrm{~N}_{4} \mathrm{O}_{2}\right]: \mathrm{C} 63.22 \%, \mathrm{H} 3.54 \%, \mathrm{~N}$ $12.29 \%, \mathrm{Cu} 13.94 \%$, found: C $63.1 \%, \mathrm{H} 3.52 \%, \mathrm{~N} 12.1 \%, \mathrm{Cu}$<smiles>O=C(C(=O)c1ccccc1)c1ccccc1</smiles>

Benzil<smiles>Nc1ncccc1O</smiles>

2-Amino-3-hydroxy pyridine

3 drops of glacial acetic acid $\mathrm{K}_{2} \mathrm{CO}_{3} / 4 \mathrm{~h}$ stirring with reflux

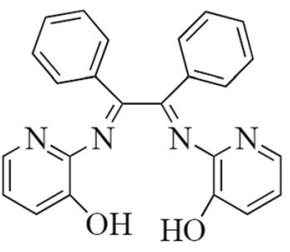

Schiff base ligand (L)

Scheme 1 Synthesis of Schiff base ligand 


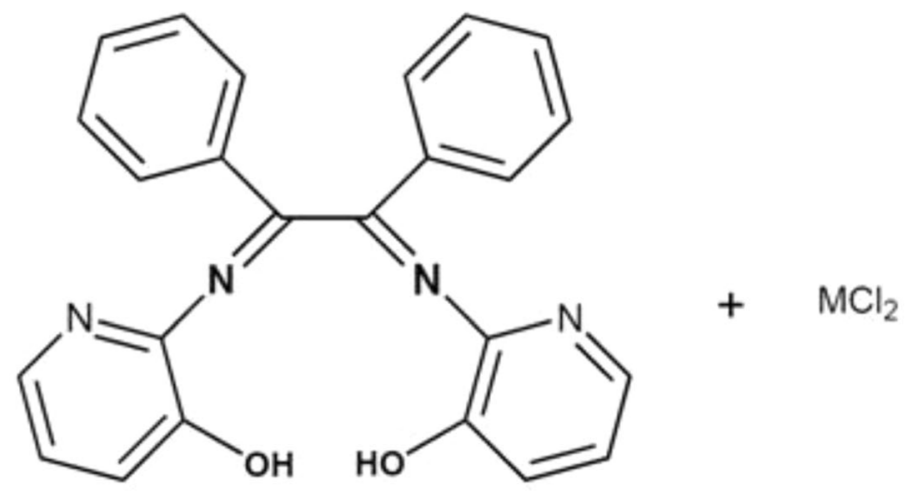

\section{Sonication for $4 \mathrm{~h}$} $12 \mathrm{~h}$ reflux/ Ethanol

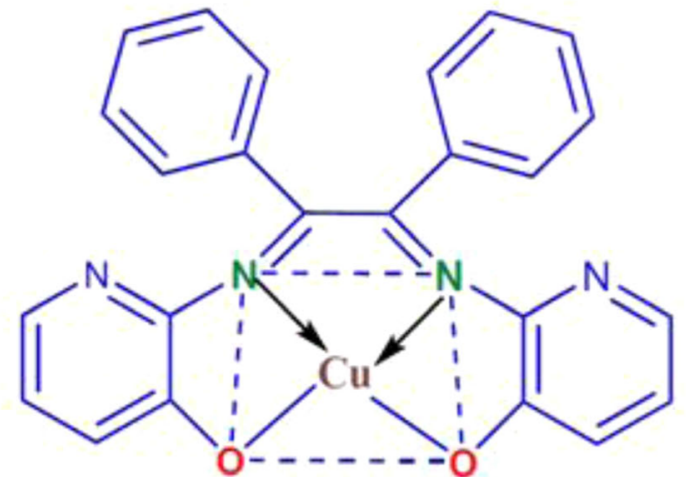

(a) Square planar geometry [CuL]

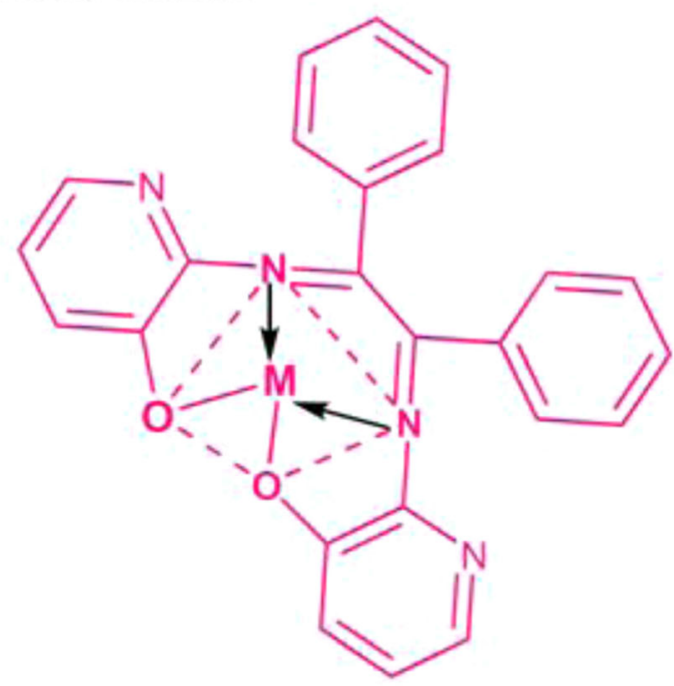

(b) Tedrahedral geometry where $\mathrm{M}=\mathrm{Co}(\mathrm{II}), \mathrm{Ni}(\mathrm{II}), \mathrm{Zn}$ (II)

Scheme 2 Synthesis of metal complexes

13.8\%; $\Lambda_{\mathrm{m}} \times 10^{-3}\left(\mathrm{ohm}^{-1} \mathrm{~cm}^{2} \mathrm{~mol}^{-1}\right)$ 12; BM: $1.81 ; \lambda_{\max }$ $\left(\mathrm{cm}^{-1}\right)$ in DMSO $18348(\mathrm{~d}-\mathrm{d})$; FT-IR $\left(\mathrm{KBr}\right.$ disc cm$\left.{ }^{-1}\right): 1578$ $v(-\mathrm{C}=\mathrm{N}), 410(\mathrm{M}-\mathrm{N}), 522(\mathrm{M}-\mathrm{O})$; ESI-MS: $456(\mathrm{M}+1) \mathrm{m} / \mathrm{z}$.

[CoL]: yield: $76 \%$; colour: pale violet; M.P: $286{ }^{\circ} \mathrm{C}$; M. Wt: 451; anal. cal. for $\left[\mathrm{CoC}_{24} \mathrm{H}_{16} \mathrm{~N}_{4} \mathrm{O}_{2}\right]$ : C $63.75 \%, \mathrm{H} 3.50 \%$, N $12.47 \%$, Co $13.06 \%$; found: C $63.67 \%$, H $3.46 \%, \mathrm{~N} 12.1 \%$, Co $13.05 \% ; \Lambda_{\mathrm{m}} \times 10^{-3}\left(\mathrm{ohm}^{-1} \mathrm{~cm}^{2} \mathrm{~mol}^{-1}\right) 14 ; \mathrm{BM}: 4.68 ; \lambda_{\max }$ $\left(\mathrm{cm}^{-1}\right)$ in DMSO 18832 (d-d); FT-IR (KBr disc cm $\left.{ }^{-1}\right): 1576$ $v(-\mathrm{C}=\mathrm{N}), 412(\mathrm{M}-\mathrm{N}), 540(\mathrm{M}-\mathrm{O})$; ESI-MS: $453 \mathrm{~m} / \mathrm{z}$.

[NiL]: yield: $83 \%$; colour: dark green; M.P: $282{ }^{\circ} \mathrm{C}$; M. Wt: 452; anal. cal. for $\left[\mathrm{NiC}_{24} \mathrm{H}_{16} \mathrm{~N}_{4} \mathrm{O}_{2}\right]$ : C $63.71 \%, \mathrm{H} 3.58 \%, \mathrm{~N}$ $12.42 \%$, Ni $13.01 \%$, found: C $63.50 \%$, H $3.56 \%$, N $12.41 \%$,
Ni $13.0 \% ; \Lambda_{\mathrm{m}} \times 10^{-3}\left(\mathrm{ohm}^{-1} \mathrm{~cm}^{2} \mathrm{~mol}^{-1}\right)$ 11; BM: 3.36; $\lambda_{\max }$ $\left(\mathrm{cm}^{-1}\right)$ in DMSO 18587 (d-d); FT-IR (KBr disc $\left.\mathrm{cm}^{-1}\right)$ : 1571 v($\mathrm{C}=\mathrm{N}$ ), $414(\mathrm{M}-\mathrm{N}), 534$ (M-O); ESI-MS: $452 \mathrm{~m} / \mathrm{z}$.

[ZnL]: yield: $85 \%$; colour: colourless; M.P: $284{ }^{\circ} \mathrm{C}$; M. Wt: 457; anal. cal. for $\left[\mathrm{ZnC}_{24} \mathrm{H}_{16} \mathrm{~N}_{4} \mathrm{O}_{2}\right]$ : C $62.96 \%$; $\mathrm{H} 3.53 \%, \mathrm{~N}$ $12.25 \%$, Zn $14.27 \%$; found: C $62.92 \%$, H $3.51 \%$, N $12.23 \%$, Zn $14.26 \% ; \Lambda_{\mathrm{m}} \times 10^{-3}\left(\mathrm{ohm}^{-1} \mathrm{~cm}^{2} \mathrm{~mol}^{-1}\right) 13 ; \mu_{\text {eff }}(\mathrm{BM}) 0$; $\lambda_{\max }\left(\mathrm{cm}^{-1}\right)$ in DMSO (transition): 24154 (LMCT)); FT-IR (KBr disc): 1575 v(-C=N), $414(\mathrm{M}-\mathrm{N}), 535(\mathrm{M}-\mathrm{O}) ;{ }^{1} \mathrm{H}$ NMR (DMSO-d ${ }_{6}$ ) (ס): (aromatic H) 7.31-8.6 (m), ${ }^{13} \mathrm{C}$ NMR $\left(\right.$ DMSO-d $\left._{6}\right)(\delta)$ : (aromatic C) 127.53, 129.23, 129.38, 129.73, $(-\mathrm{C}=\mathrm{N})$ 156.18, (-C-O) 161.18; MS: $458 \mathrm{~m} / \mathrm{z}$. 


\section{Results and discussion}

\section{Elemental analysis and molar conductance}

The reports of spectral and analytical studies signified that compounds are found to be stable and crystalline in nature. The ligand is soluble in ethanol and acetone and its metal complexes are freely soluble in DMSO and DMF. The elemental analysis of the Schiff base ligand and metal complexes concurred well with the proposed structure. The obtained low molar conductance revealed that the complexes are nonelectrolytic in nature. The mechanism of Schiff base ligand and metal complexes are mentioned in Schemes 1 and 2 respectively.

\section{Magnetic susceptibility measurement}

Magnetic susceptibility measurement is an assessment that provides the sufficient information to characterize the structure of metal complexes. The magnitude of the paramagnetic effect is measured in terms of the magnetic moment $(\mu)$. The larger the magnitude of $\mu$, the greater the paramagnetism of the compound is. The magnetic moment has contributions from the spin and orbital angular momentum. The magnetic properties are owing to the presence of unpaired electrons in the partially filled dorbital in the outer shell of the compound. These values provide an explanation of the electronic state of the metal in the complexes.

The observed magnetic moment value for the synthesized $\mathrm{Cu}(\mathrm{II})$ complex exhibits $1.81 \mathrm{BM}$. These values are slightly higher than the spin only value of 1.73 $\mathrm{BM}$, and it is due to the spin-orbit coupling followed by lowering of symmetry [20]. Therefore, the copper complex shows the square planar geometry. Cobalt complex displays the magnetic moment value of $4.68 \mathrm{BM}$, which is the sum of contributions due to spin only moments and spin-orbit coupling. Thus, the Co(II) complex shows the tetrahedral geometry. The magnetic moment value 3.36 BM for $\mathrm{Ni}(\mathrm{II})$ complex is closely consistent with tetrahedral geometry. But the zinc complex does not exhibit any $d-d$ transition owing to its filled $\mathrm{d}^{10}$ electronic configuration and possesses zero magnetic moment value.

\section{Fourier transform infrared spectra}

This is a spectrum, which suggests an essential record of the nature of functional groups linked to the metal centre. This analysis provides vital information about the mode of bonding of the ligand with the metal ion. The attempt has been made to produce a crystal, which is to be characterized by XRD, but unable to succeed. In Schiff base ligand, the strong band noticed at $1592 \mathrm{~cm}^{-1}$ is attributed to the $(-\mathrm{C}=\mathrm{N})$ stretching vibration band, and in complexes, these vibrations underwent a bathochromic shift (lower frequency) $1580-1570 \mathrm{~cm}^{-1}$ upon coordination representing the chelation of $\mathrm{N}$ atom of the imine group $(-\mathrm{C}=\mathrm{N})$ of the free ligand to the central metal ion [21]. In ligand, the broad band aroused at $3437 \mathrm{~cm}^{-1}$ is related to the $(-\mathrm{OH})$ group extending vibration. In metal complexes, this band gets vanished, which denotes the deprotonation of the hydroxyl group and involvement of phenolic oxygen with metal upon coordination. It is caused by the transfer of electrons from $\mathrm{N}$ to the empty d-orbital of the metal atom. The mode of the chelation was further recommended by arising two new bands in the far infrared region of the complexes around $543-511 \mathrm{~cm}^{-1}$ and $422-406 \mathrm{~cm}^{-1}$ that are assigned to the $v(\mathrm{M}-\mathrm{O})$ and $v(\mathrm{M}-\mathrm{N})$ vibrations respectively, which help to identify the participation of $\mathrm{N}$ atom of $(-\mathrm{C}=\mathrm{N})$ group and oxygen atom of the $(-\mathrm{OH})$ group of the ligand upon chelation. The FT-IR spectra of the ligand and metal complexes are portrayed from Figs. S1.1 to S1.5.

\section{Ultraviolet spectra}

This spectrum is used to distinguish different geometry of the metal complexes. The ligand displays the two absorption bands, the weak band at $37037 \mathrm{~cm}^{-1}$ is owing to the $\pi \rightarrow \pi^{*}$ stacking interaction of aromatic groups of Schiff base, and a strong band appeared at $31152 \mathrm{~cm}^{-1}$ for $\mathrm{n} \rightarrow \pi^{*}$ transition of $\mathrm{C}=\mathrm{N}$ group of Schiff base. These bands have some alterations in complex spectra, which imply the coordination of ligand to the metal centre. Copper, cobalt and nickel complexes have generated the unique band of $\mathrm{d}-\mathrm{d}$ transition, and it is utilized to predict the geometry. The electronic spectra of the ligand and complexes are displayed in Figs. S2.1-S2.4.

Copper complex exhibits a broad d-d absorption band at $18348 \mathrm{~cm}^{-1}$, which is consonant with ${ }^{2} \mathrm{~B}_{1} \mathrm{~g} \rightarrow{ }^{2} \mathrm{~A}_{1} \mathrm{~g}$ transition, and the value highly supports the $\mathrm{Cu}$ (II) complex that has square planar geometry [22-24].

From the literature survey, previously reported tetrahedral cobalt complexes have one absorption band in the visible region due to ${ }^{4} \mathrm{~A}_{2}(\mathrm{~F}) \rightarrow{ }^{4} \mathrm{~T}_{1}(\mathrm{P})$ transition [20]. The UV-spectrum of synthesized cobalt complex has only one absorption band at $18832 \mathrm{~cm}^{-1}$ due to ${ }^{4} \mathrm{~A}_{2}(\mathrm{~F}) \rightarrow{ }^{4} \mathrm{~T}_{1}(\mathrm{P})$ transition [20], which indicates cobalt complex has tetrahedral geometry [22].

The spectrum of $\mathrm{Ni}$ (II) complex shows one intensity band at $18587 \mathrm{~cm}^{-1}$, owing to the ${ }^{3} \mathrm{~T}_{1}(\mathrm{~F}) \rightarrow{ }^{3} \mathrm{~T}_{1}(\mathrm{P})$ transition recommending tetrahedral geometry which is a good correlation with tetrahedral complexes [22-24].

$\mathrm{Zn}$ (II) complex produces the charge transfer spectral band at $24,154 \mathrm{~cm}^{-1}$ which is corresponding to charge transfer transition between ligand to metal, which signified that zinc complex has tetrahedral geometry [25]. The proposed structure of the complexes is portrayed in Fig. 1. 
Fig. 1 Proposed structure of Schiff base metal complexes a square planar geometry for $\mathrm{Cu}$ (II) complex and $\mathbf{b}$ tetrahedral geometry for $\mathrm{Co}(\mathrm{II}), \mathrm{Ni}(\mathrm{II})$ and $\mathrm{Zn}(\mathrm{II})$ complexes

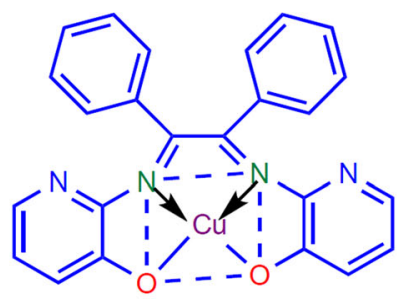

(a) Square planar geometry [CuL]

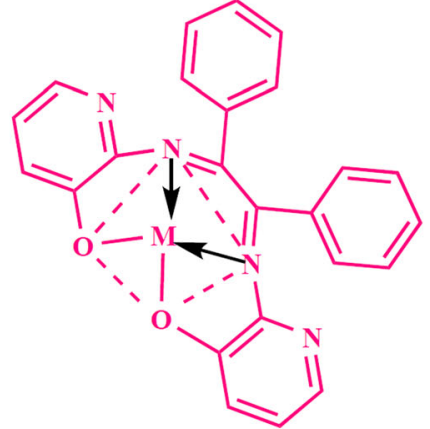

(b) Tetrahedral geometry where $\mathrm{M}=\mathrm{Co}$ (II), $\mathrm{Ni}(\mathrm{II})$ and $\mathrm{Zn}(\mathrm{II})$

\section{${ }^{1} \mathrm{H}$ and ${ }^{13} \mathrm{C}$ NMR spectral studies}

The ${ }^{1} \mathrm{H}$ NMR spectrum of Schiff base ligand (L) and its diamagnetic $\mathrm{Zn}(\mathrm{II})$ complex was recorded in DMSO- $\mathrm{d}_{6}$ solution. The spectrum of the ligand displays the multiplet in the range of 7.33-8.27 ppm, which is analogous with the aromatic protons in the compound [26]. In ligand, the peak at $9.63 \mathrm{ppm}$ is attributed to $(-\mathrm{OH})$ protons in the pyridine moiety. But in the case of complex, there is no $(-\mathrm{OH})$ characteristic peak that appears, which means the deprotonation of the $(-\mathrm{OH})$ group and the formation of $\mathrm{M}-\mathrm{O}$ bond upon chelation [27]. In complex, multiplet
Fig. 2 Mass fragmentation pattern of ligand

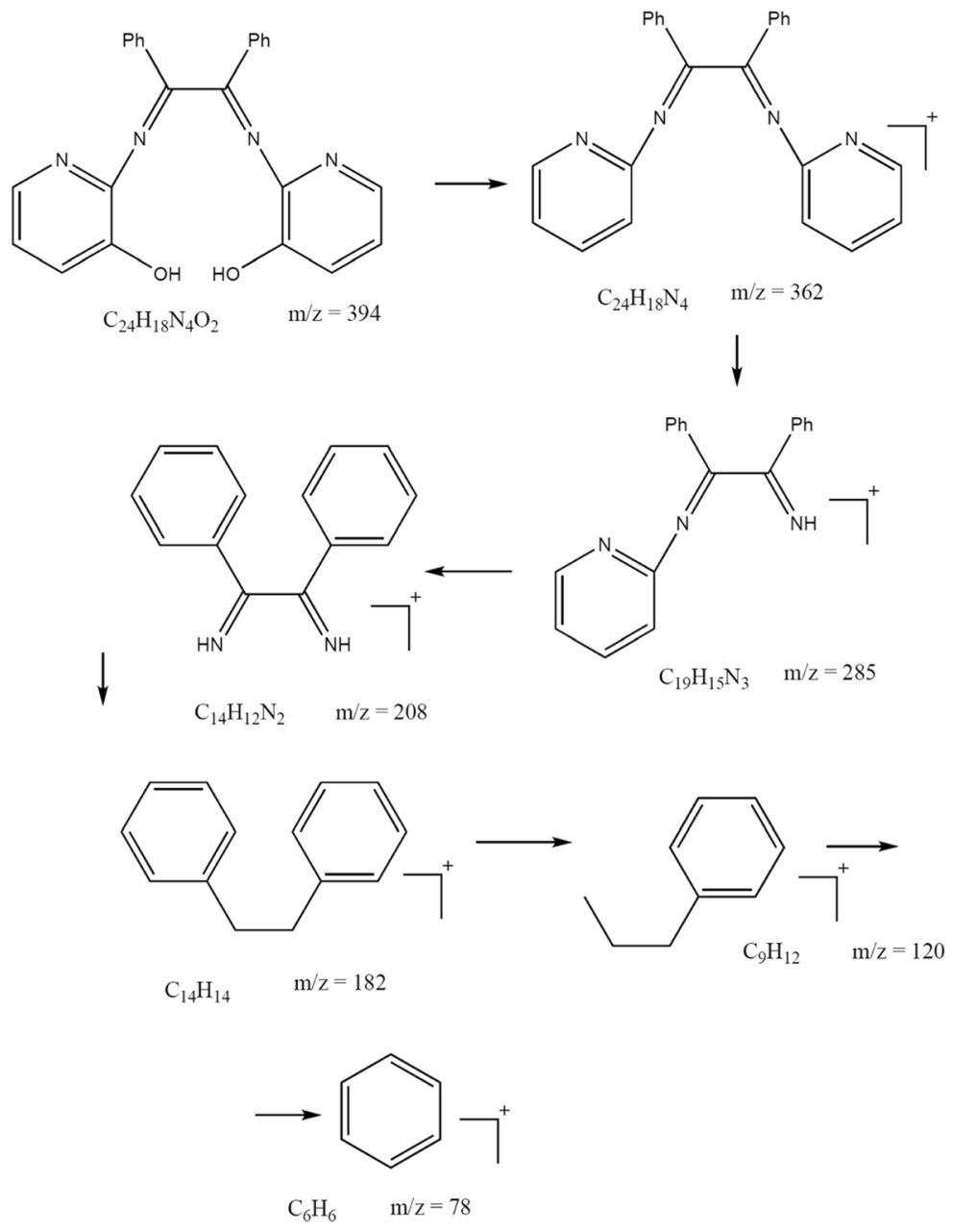


Fig. 3 Mass fragmentation pattern $\mathrm{Cu}$ (II) complex

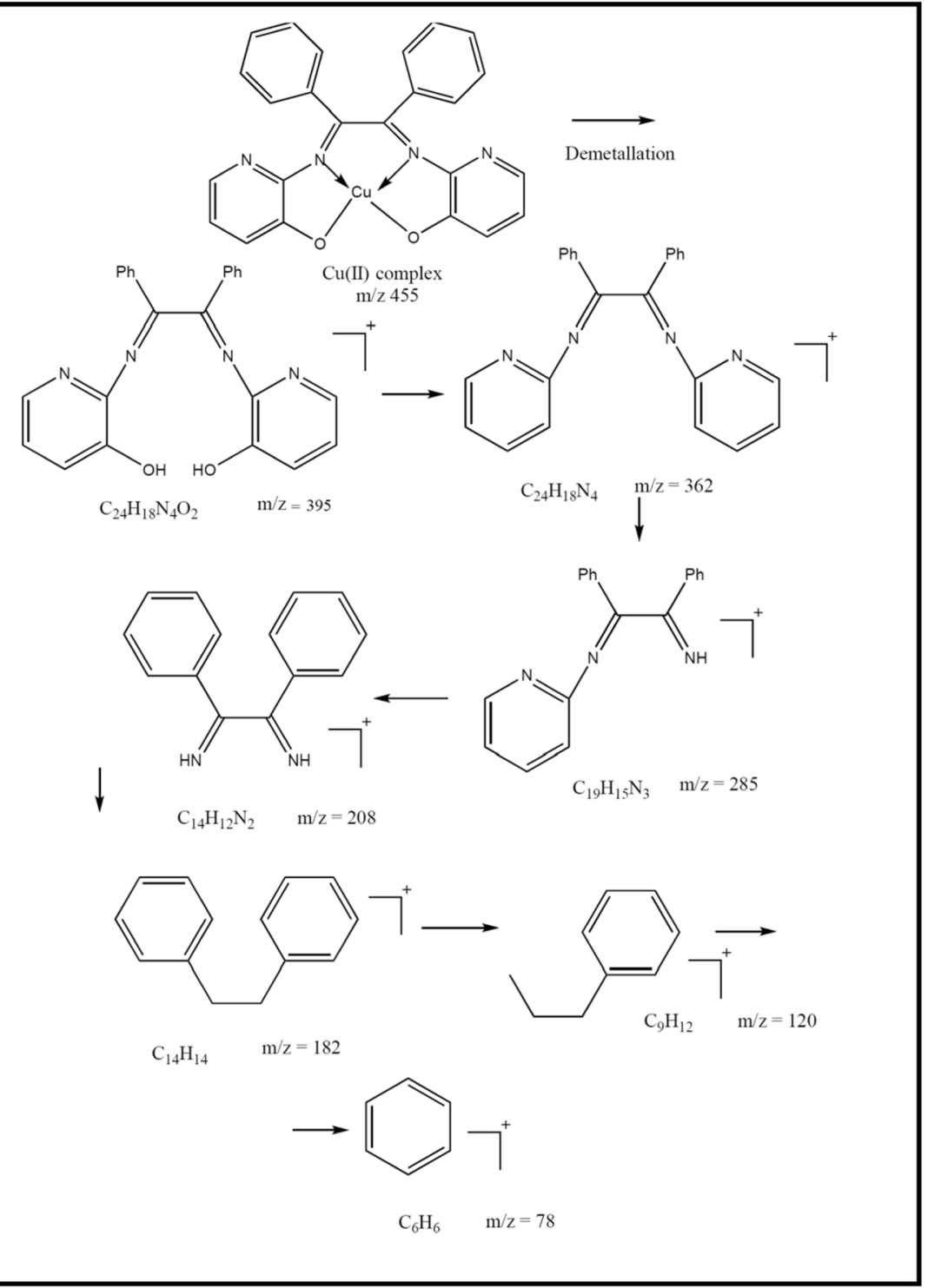

peaks appeared around 7.31-8.60 ppm, which is associated with aromatic protons. Besides, there are not many changes in other signals in the complex spectrum. The ${ }^{1} \mathrm{H}$ NMR spectrum of the ligand and their $\mathrm{Zn}$ (II) complex are represented in Figs. S3.1 and S3.2.

The ${ }^{13} \mathrm{C}$ NMR spectrum of the ligand (Fig. S4.1) notifies the carbon environment of the phenyl group around 125.05$131.92 \mathrm{ppm}$ and $(-\mathrm{C}=\mathrm{N})$ signals at $158.19 \mathrm{ppm}$. In the case of

Table 1 The spin Hamiltonian parameters of the $\mathrm{Cu}$ (II) complex in DMSO solution at LNT

\begin{tabular}{|c|c|c|c|c|c|c|c|}
\hline \multirow[t]{2}{*}{ Complex } & \multicolumn{3}{|c|}{ g-tensor } & \multicolumn{3}{|c|}{$\mathrm{A} \times 10^{-4}\left(\mathrm{~cm}^{-1}\right)$} & \multirow[t]{2}{*}{ G } \\
\hline & $\mathrm{g}_{\|}$ & $\mathrm{g}_{\perp}$ & $\mathrm{g}_{\text {iso }}$ & $\mathrm{A}_{\|}$ & $\mathrm{A}_{\perp}$ & $\mathrm{A}_{\text {iso }}$ & \\
\hline $\mathrm{Cu}(\mathrm{II})$ & 2.33 & 2.09 & 2.11 & 132 & 29 & 68 & 4.8 \\
\hline
\end{tabular}

zinc complex (Fig. S4.2), imine group relocated to $156.18 \mathrm{ppm}$ represents the chelation of the imine group to the metal centre. It is due to the transfer of electrons from $\mathrm{N}$ to the central metal ion and recommended the development of $\mathrm{M}-\mathrm{N}$ bond upon chelation. In ligand, the peak corresponds to $(-\mathrm{C}-\mathrm{OH})$ group at $165.16 \mathrm{ppm}$, but in zinc complex, this characteristic peak has deviated to $161.18 \mathrm{ppm}$, which implies the deprotonation of $(-\mathrm{OH})$ and development of $\mathrm{M}-\mathrm{O}$ bond during chelation. Furthermore, there are no considerable alterations in other signals of the complex spectrum.

\section{Mass spectra}

Mass spectrum and molecular ion peaks are committed to the proposed formulae of the synthesized compounds. The fragmented peaks of Schiff base ligand and copper complex are shown in Figs. 2 and 3. The molecular ion peak at $\mathrm{m} / \mathrm{z}=$ 


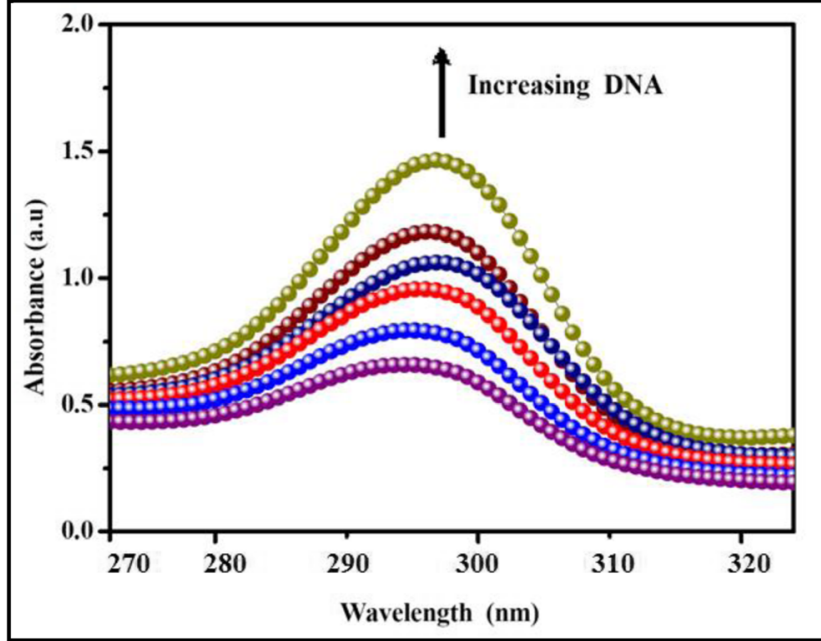

Fig. 4 The electronic absorption spectrum of Schiff base ligand in $5 \mathrm{mM}$ Tris- $\mathrm{HCl} / 50 \mathrm{mM} \mathrm{NaCl}$ buffer $(\mathrm{pH}=7.2$ at $298 \mathrm{~K}$ ) in the presence of increasing amount of CT-DNA

395 equivalent to its molecular weight of Schiff base ligand $(\mathrm{M}+1)$ has the formula $\left[\mathrm{C}_{24} \mathrm{H}_{18} \mathrm{~N}_{4} \mathrm{O}_{2}\right]^{+}$. The fragmentation peaks noticed for ligand at $\mathrm{m} / \mathrm{z} 362,285,208,182,120$ and 78 are from the scission of $\left[\mathrm{C}_{24} \mathrm{H}_{18} \mathrm{~N}_{4}\right]^{+},\left[\mathrm{C}_{19} \mathrm{H}_{15} \mathrm{~N}_{3}\right]^{+}$, $\left[\mathrm{C}_{14} \mathrm{H}_{12} \mathrm{~N}_{2}\right]^{+},\left[\mathrm{C}_{14} \mathrm{H}_{14}\right]^{+},\left[\mathrm{C}_{9} \mathrm{H}_{12}\right]^{+}$and $\left[\mathrm{C}_{6} \mathrm{H}_{6}\right]^{+}$respectively.

The mass fragmentation for copper, cobalt, nickel and zinc compounds produce the molecular ion peaks at $\mathrm{m} / \mathrm{z}$ 456, 453, 452, and 458 respectively. In Fig. 2, the copper compound displays peak at $456(\mathrm{M}+1)$, which is on demetallation; it gives the molecular ion peak of ligand $(\mathrm{M}+1)$, which posses $\mathrm{m} / \mathrm{z}=395$ equals to the ligand molecular formula $\left[\mathrm{C}_{24} \mathrm{H}_{18} \mathrm{~N}_{4} \mathrm{O}_{2}\right]^{+}$followed by the formation of $\left[\mathrm{C}_{24} \mathrm{H}_{18} \mathrm{~N}_{4}\right]^{+},\left[\mathrm{C}_{19} \mathrm{H}_{15} \mathrm{~N}_{3}\right]^{+},\left[\mathrm{C}_{14} \mathrm{H}_{12} \mathrm{~N}_{2}\right]^{+},\left[\mathrm{C}_{14} \mathrm{H}_{14}\right]^{+}$, $\left[\mathrm{C}_{9} \mathrm{H}_{12}\right]^{+}$and $\left[\mathrm{C}_{6} \mathrm{H}_{6}\right]^{+}$fragmentation peaks. The $\mathrm{m} / \mathrm{z}$ value

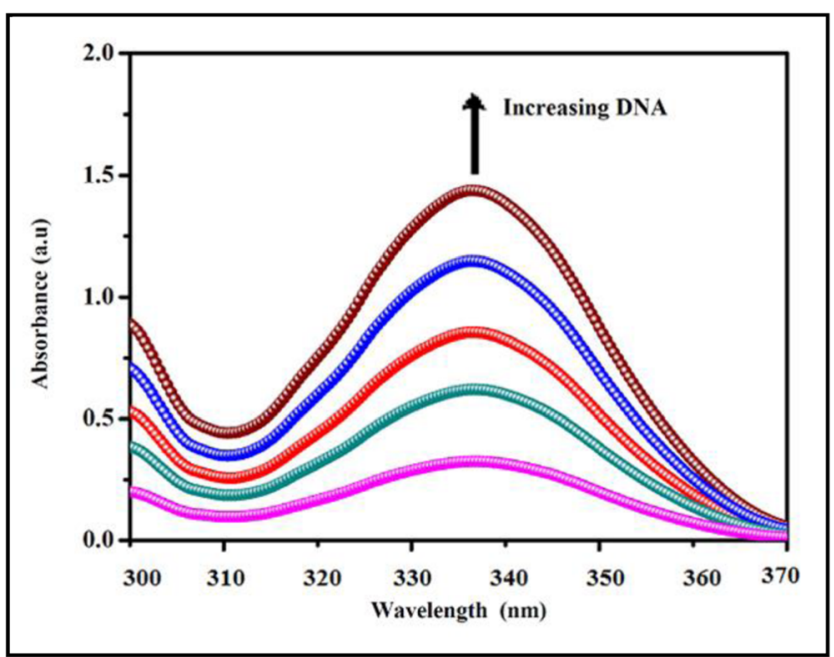

Fig. 5 The electronic absorption spectrum of [CuL] in $5 \mathrm{mM}$ Tris- $\mathrm{HCl} /$ $50 \mathrm{mM} \mathrm{NaCl}$ buffer $(\mathrm{pH}=7.2$ at $298 \mathrm{~K}$ ) in the presence of increasing amount of CT-DNA

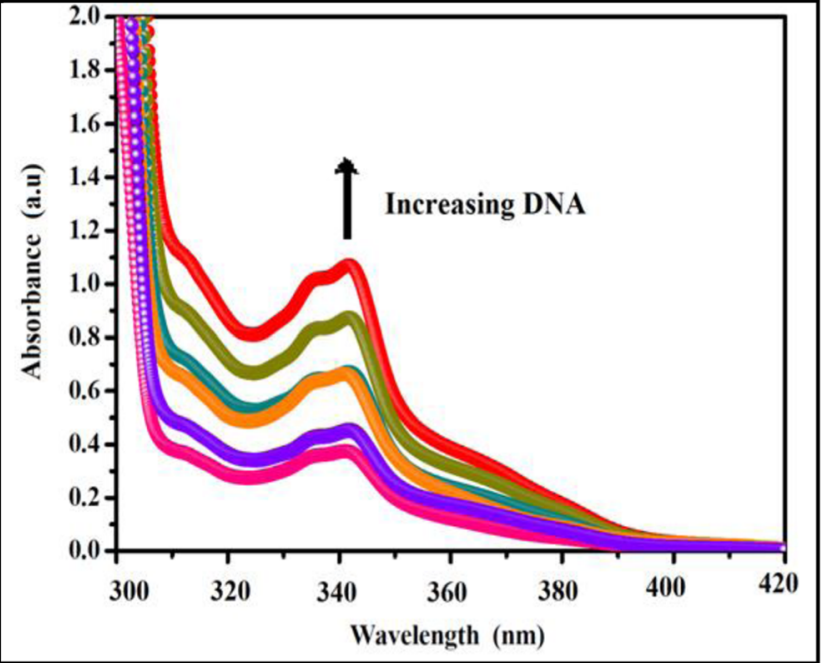

Fig. 6 The electronic absorption spectrum of [CoL] in $5 \mathrm{mM}$ Tris- $\mathrm{HCl} /$ $50 \mathrm{mM} \mathrm{NaCl}$ buffer $(\mathrm{pH}=7.2$ at $298 \mathrm{~K})$ in the presence of increasing amount of CT-DNA

of all the fragmented peaks authenticates the stoichiometry of the complexes [28]. The mass spectra of the compounds are represented in Figs. S5.1 to S5.5.

\section{Electron paramagnetic spectroscopy}

Electron paramagnetic spectroscopy (EPR) spectra provide information on the distribution of unpaired electrons and character of the bonding between metal to ligand [29]. The spectra were taken in DMSO at room temperature and liquid nitrogen temperature (LNT). Figure S6.1 signifies the single absorption band in the high field and is isotropic owing to the tumbling motion

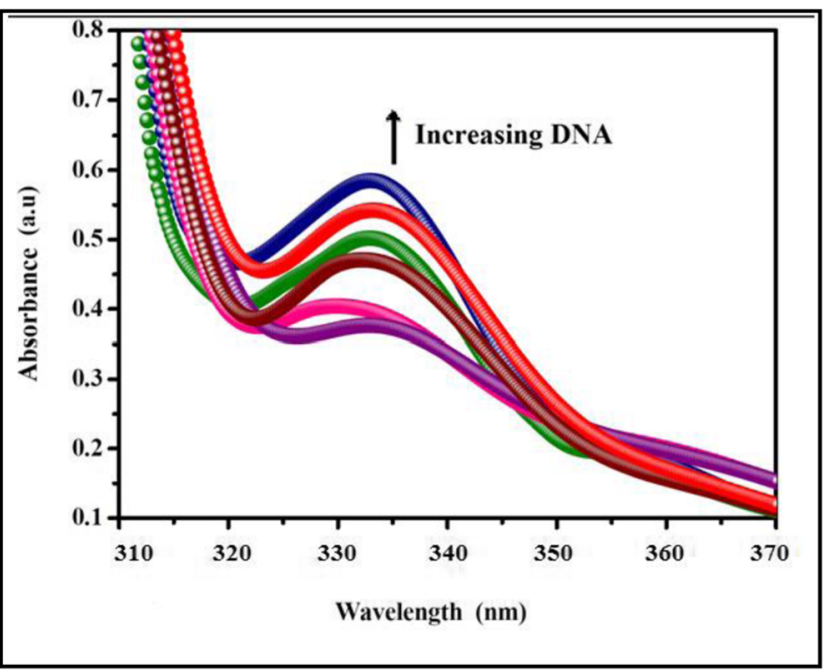

Fig. 7 The electronic absorption spectrum of [NiL] in $5 \mathrm{mM}$ Tris- $\mathrm{HCl} /$ $50 \mathrm{mM} \mathrm{NaCl}$ buffer $(\mathrm{pH}=7.2$ at $298 \mathrm{~K}$ ) in the presence of increasing amount of CT-DNA 


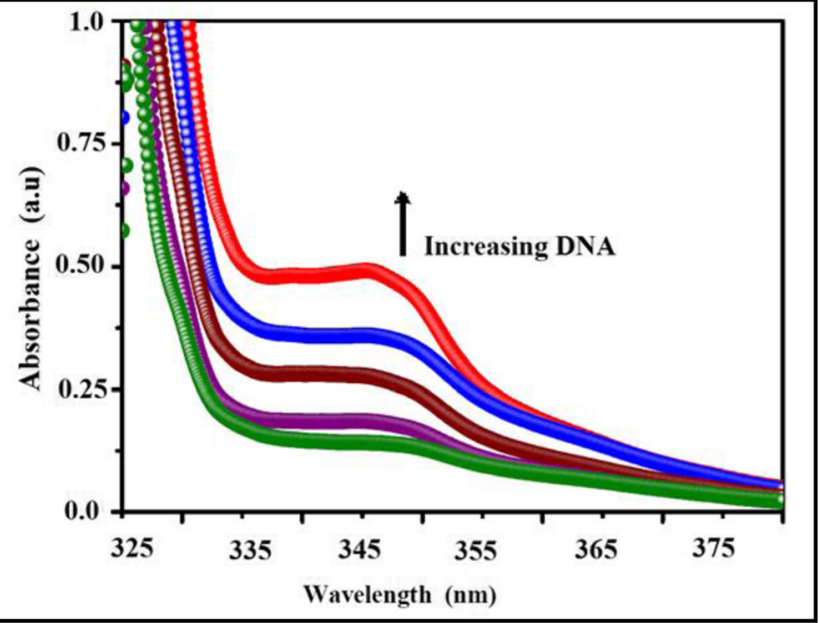

Fig. 8 The electronic absorption spectrum of $[\mathrm{ZnL}]$ in $5 \mathrm{mM}$ Tris- $\mathrm{HCl} /$ $50 \mathrm{mM} \mathrm{NaCl}$ buffer $(\mathrm{pH}=7.2$ at $298 \mathrm{~K}$ ) in the presence of increasing amount of CT-DNA

of the molecules. Fig. S6.2 shows three peaks with low intensities in the low field area. The EPR parameters of the copper complex at $77 \mathrm{~K}$ are measured and listed in Table 1. The $\mathrm{Cu}(\mathrm{II})$ complex notices the distinctive axially symmetric g-tensor values $\mathrm{g}_{\|}(2.33)>\mathrm{g}_{\perp}>(2.09)>$ $\mathrm{g}_{\mathrm{e}}>$ (2.0023), $\mathrm{A}_{\|}=132>\mathrm{A}_{\perp}=29$, signifying that the copper complex has square planar geometry [30, 31]. In this investigation, $g_{\|} / A_{\|}$value is 176 , which signifies that the copper complex keeps a non-distorted squareplanar geometry. The geometrical parameter of $\mathrm{G}$ mentions the exchange interaction among multiple $\mathrm{Cu}$ (II) centres. It is measured by deriving the formula

$\mathrm{G}=\left(\mathrm{g}_{\|}-2\right) /\left(\mathrm{g}_{\perp}-2\right)$

The degree of $\mathrm{G}$ value is measured by calculating the g-tensor using the equation $\mathrm{G}=\mathrm{g}_{||}-2.0023 / \mathrm{g}_{\perp}-2.0023$. While $\mathrm{G}$ is above four, there is no interaction between the copper centres. If not, the exchange interactions are detectable. For this research, $\mathrm{G}$ value is 4.8 , which implies that $\mathrm{Cu}(\mathrm{II})$ presents in a parallel arrangement or

Table 2 Electronic absorption parameters for the interaction of DNA with Schiff base ligand, $\mathrm{Cu}(\mathrm{II}), \mathrm{Co}(\mathrm{II}), \mathrm{Ni}(\mathrm{II})$ and $\mathrm{Zn}$ (II) complexes

\begin{tabular}{|c|c|c|c|c|c|}
\hline \multirow[t]{2}{*}{ Complex } & \multicolumn{2}{|c|}{$\lambda \max$} & \multirow[t]{2}{*}{$\Delta \lambda(\mathrm{nm})$} & \multirow[t]{2}{*}{${ }^{\mathrm{a}} \mathrm{H} \%$} & \multirow[t]{2}{*}{$\mathrm{K}_{\mathrm{b}}\left(\mathrm{M}^{-1}\right)$} \\
\hline & Free & Bound & & & \\
\hline Ligand & 293 & 295 & 2 & 11.8 & $3.6 \times 10^{4}$ \\
\hline $\mathrm{Cu}(\mathrm{II})$ & 333 & 339 & 6 & 25.6 & $6.6 \times 10^{5}$ \\
\hline $\mathrm{Co}(\mathrm{II})$ & 335 & 350 & 5 & 21.2 & $6.1 \times 10^{5}$ \\
\hline $\mathrm{Ni}(\mathrm{II})$ & 338 & 342 & 4 & 18.7 & $5.7 \times 10^{5}$ \\
\hline $\mathrm{Zn}(\mathrm{II})$ & 343 & 346 & 3 & 17.3 & $5.2 \times 10^{5}$ \\
\hline
\end{tabular}

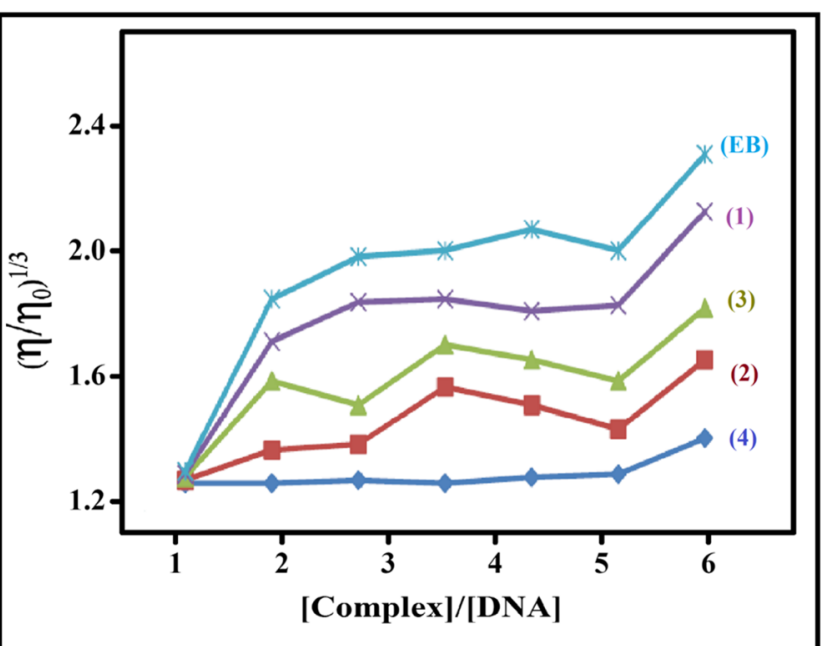

Fig. 9 Effects of increasing amount of classical intercalator $[\mathrm{EB}]$ and complexes on the relative viscosity of CT-DNA in $5 \mathrm{mmol}$ Tris-HCl/ $50 \mathrm{mmol} \mathrm{NaCl}$ buffer at room temperature, where (1) $\mathrm{Cu}$ (II), (2) $\mathrm{Co}$ (II), (3) $\mathrm{Ni}$ (II) and (4) $\mathrm{Zn}$ (II) complexes

misarranged to some extent and exchange interaction has not been seen in the $\mathrm{Cu}(\mathrm{II})$ complex [32]. The obtained $\mathrm{g}_{\|} / \mathrm{A}_{\|}$value of the $\mathrm{Cu}$ (II) complex is 176 , which supports that the $\mathrm{Cu}$ (II) complex has square planar geometry [33].

\section{X-ray powder diffraction spectra}

XRD analysis has been used to verify the crystalline and amorphous nature of the compounds. The XRD patterns of the synthesized compounds display wellsharpened peaks, which indicate the crystalline phase of the compounds [34]. By correlating the XRD pattern of ligand and complexes, the metal complexes show a few new peaks, which support the chelation [35]. The size of the crystalline compounds is estimated by Debye Scherer's formula:

$\mathrm{D}=0.9 \lambda / \beta \cos \theta$

where constant 0.9 is the shape factor; $\lambda, \theta, \beta$ denote $\mathrm{X}$-ray wavelength (1.5406 $\AA$ ), Bragg diffraction angle and full width at half maximum (FWHM) respectively. The average crystallite sizes of ligand, copper, cobalt, nickel and zinc compounds are 34, 36, 41, 17 and $57 \mathrm{~nm}$ respectively. The powder XRD pattern of the compounds is portrayed from S7.1 to S7.5.

\section{Morphological prediction}

The SEM images of the compounds have the uniform crystalline sizes with 1-10 $\mu \mathrm{m}$. The synthesized ligand, copper, cobalt, nickel and zinc compounds possess flakes, cubic, spherical, micro sponge and rod-like appearances respectively. The 

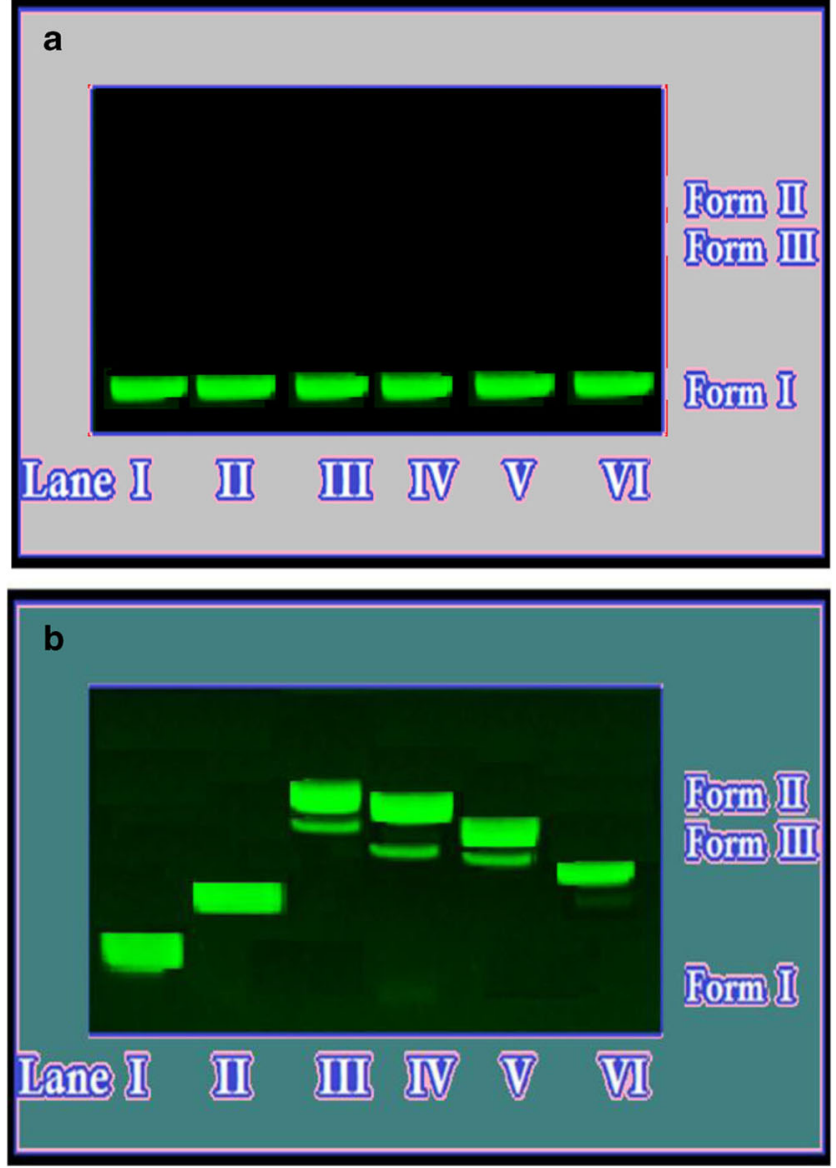

Fig. 10 a DNA cleavage in the absence of $\mathrm{H}_{2} \mathrm{O}_{2}$. Lane 1: DNA control; Lane 2: DNA+ L $(60 \mu \mathrm{M})$; Lane 3: DNA+ Cu(II) $(60 \mu \mathrm{M})$; Lane 4: DNA+ Co(II) $(60 \mu \mathrm{M})$; Lane 5: DNA+ Ni(II) $(60 \mu \mathrm{M})$; Lane 6: DNA+ $\mathrm{Zn}$ (II) $(60 \mu \mathrm{M})$. b DNA cleavage in the presence of $\mathrm{H}_{2} \mathrm{O}_{2}$. Lane 1: DNA control; Lane 2: DNA+ L (60 $\mu \mathrm{M})$; Lane 3: DNA+ Cu(II) $(60 \mu \mathrm{M})$; Lane 4: DNA+ Co(II) $(60 \mu \mathrm{M})$; Lane 5: DNA+ Ni(II) $(60 \mu \mathrm{M})$; Lane 6: DNA+ $\mathrm{Zn}(\mathrm{II})(60 \mu \mathrm{M})$

SEM images of the Schiff base ligand (L) and complexes are displayed in Fig. S8.

\section{Biological studies}

\section{DNA interaction studies}

Deoxyribonucleic acid is an essential component in the living cells, which possesses the genetic information passes from one generation to another generation. DNA binding analysis is a significant investigation for developing the novel-based therapeutic drugs. DNA binding aptitude of the synthesized compounds has been scrutinized by two different experiments such as electronic absorption titration and hydrodynamic analysis. These are the analyses, which interpret the bonding potential between DNA and prepared compounds.

\section{Electronic absorption spectral titration}

The interaction of the compound with DNA gives strong evidence for the establishment of anticancer medicines. The structural changes in DNA filaments are linked to anticarcinogenic activity [36, 37]. The UV-visible spectra of the synthesized compounds with or without CT-DNA are specified from Figs. 4, 5, 6, 7 and 8 .

The addition of the DNA solution to the synthesized compounds, which leads to the alteration in the ligand to metal charge transfer band, is a basic concept involved in DNA binding analysis. The spectrum is taken by regulating the concentration of compounds stable $\left(10^{-3} \mathrm{M}\right)$ and changing the DNA concentration with $5 \mathrm{mM}$ Tris- $\mathrm{HCl} / 50 \mathrm{mM} \mathrm{NaCl}$ buffer solution $(\mathrm{pH}=7.2)$. The small alterations in absorption value cause wavelength shift leading to hypochromism [38]. The hypochromism is owing to the formation of stacking interactions between the nucleic acid and aromatic chromophores of the prepared compounds and penchant with CT-DNA by intercalation. At the time of intercalative mode, the p-orbital of the synthesized compounds could be coupled with p-orbital of the base pairs, which decreases the transition energy and induces hypochromism. The hypochromicity $(\mathrm{H} \%)$ of the synthesized complexes display $\sim 16-25 \%$, which implies that all the complexes are firmly bound with CT-DNA. As a result, the intercalative mode between CT-DNA and complexes is very well supported [39-42]. The binding affinity of complexes is greater than ligand owing to the extra $\pi-\pi^{*}$ interaction via the aromatic chromophores. In general, the strength of the absorption shift is mutually correlated with the MLCT band, which is indirectly connected with the potency of intercalation mode.

Intercalation mechanism initiated the strong stacked interaction between the aromatic chromophore and the base pair of DNA $[43,44]$. From the outputs, it is confirmed that the ligand itself plays as a puny intercalator, but the metal complexes act as strong intercalators due to the obtained greater $\mathrm{H} \%$ values. The intrinsic binding constant values of $\mathrm{K}_{\mathrm{b}}$ are calculated by the plot of $[\mathrm{DNA}] /(\varepsilon \mathrm{b}-\varepsilon \mathrm{f})$ and $[\mathrm{DNA}]$ which are represented in Table 2.

\section{Hydrodynamic measurements}

The binding of ligand and metal complexes with deoxyribonucleic acid which leads to the change in the viscosity is considered as an essential analysis in the absence of crystallographic reports. This is another measurement for predicting metal-DNA interaction mode $[45,46]$. Ethidium bromide (EB) is used for an intercalating agent. The incremental addition of complexes to the DNA, which created the progressive expanding of the DNA viscosity, added another witness for intercalative mode [47-49]. The EB enhances the relative viscosity of DNA filaments, which leads to intercalation. But 
Fig. 11 The antibacterial activity of the synthesized compounds

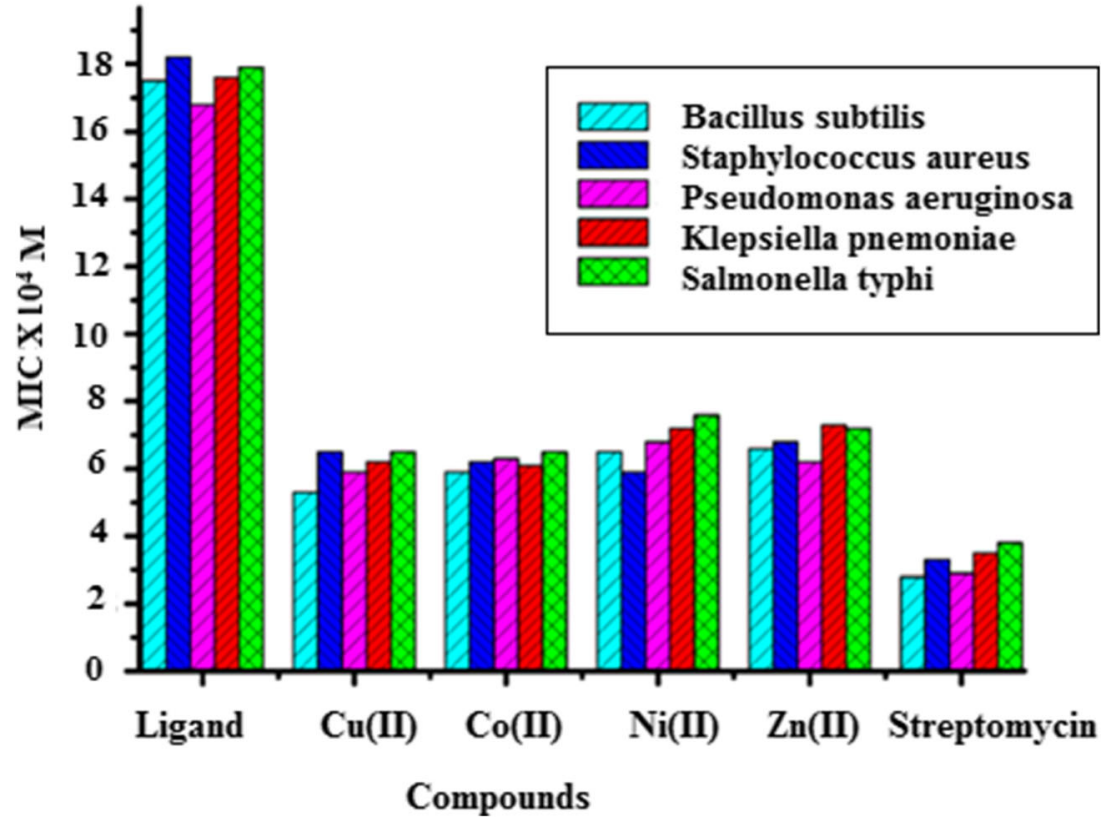

partial and non-classical intercalative compound could distort the DNA double-strand and diminishes the DNA viscosity $[50,51]$. The outputs highly coincided with the intercalative mode between complexes and DNA strands. If the binding mode is electrostatic and groove binding, there is no effect on viscosity values.

The viscosity measurement data is exposed in Fig. 9. It is expressed that synthesized compounds can interact with the DNA base pair and generate an enlargement of the DNA loop and thus increase the relative viscosity of DNA solution. In this experiment, the viscosity of the compounds is estimated by the plot of $\left(\eta / \eta_{\mathrm{o}}\right)^{1 / 3}$ verses [Complex]/[DNA], where $\eta$ and $\eta_{\mathrm{o}}$ indicated the existence and non-existence of complexes to the DNA solution.

\section{Gel electrophoresis}

Finding DNA cleavage ability is very much important to recognize the synthetic route and to establish new manmade nucleases. DNA cleavage consists of the following steps: in the first stage, the relaxation of supercoiled form (SC form-1); in the second stage, the formation of the nicked circular form (NC form-2); in the last stage, the transformation of a linear form (form-3). The experiment
Fig. 12 The antifungal activity of the synthesized compounds

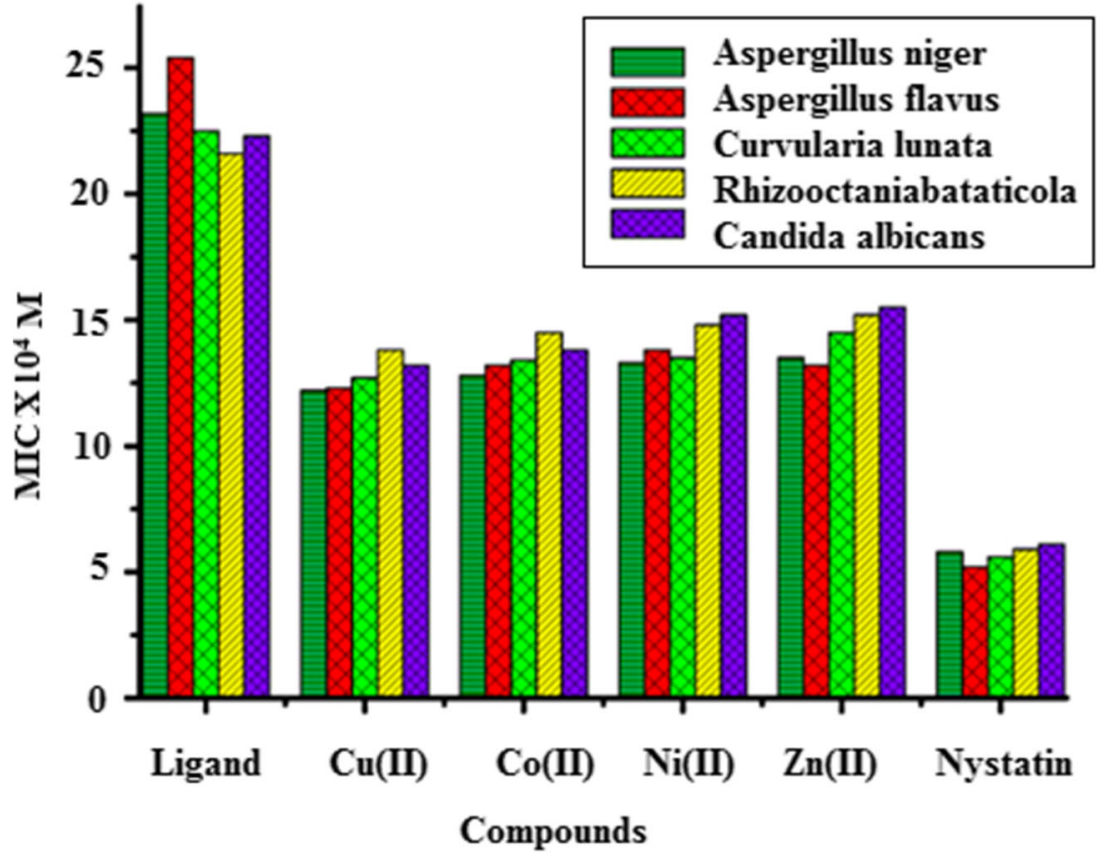


Table 3 Minimum inhibitory concentration of the synthesized free ligand and its metal complexes against the growth of bacteria ( $\mu \mathrm{M})$

\begin{tabular}{llllll}
\hline \multirow{2}{*}{ Compound } & \multicolumn{2}{l}{ MIC values $\left(\times 10^{4} \mu \mathrm{M}\right) \mathrm{SEM}= \pm 1.5$} & & \\
\cline { 2 - 6 } & Bacillus subtilis & Staphylococcus aureus & Pseudomonas aeruginosa & Klebsiella pneumoniae & Salmonella typhi \\
\hline Ligand & 17.5 & 18.2 & 16.8 & 17.6 & 17.9 \\
$\mathrm{Cu}(\mathrm{II})$ & 5.3 & 6.5 & 5.9 & 6.2 & 6.5 \\
$\mathrm{Co}(\mathrm{II})$ & 5.9 & 6.2 & 6.3 & 6.1 & 7.2 \\
$\mathrm{Ni}(\mathrm{II})$ & 6.5 & 5.9 & 6.8 & 7.3 & 7.6 \\
Zn(II) & 6.6 & 6.8 & 6.2 & 3.5 & 7.2 \\
Streptomycin & 2.8 & 3.3 & 2.9 & & 3.8 \\
\hline
\end{tabular}

is carried out by using plasmid pUC 18 DNA with metal(II) complexes with or without activator (hydrogen peroxide). During electrophoresis, the fast-moving form 1 moved to the $\mathrm{NC}$ form and finally linear form. All the synthesized complexes split the DNA strands effectively with an oxidising agent. In the absence of activator, there was a null effect upon electrophoresis (Fig. 10a).

From the analysis, it is obvious that the metal compounds have snipped the nucleic acid strand efficiently with $\mathrm{H}_{2} \mathrm{O}_{2}$ (Fig. 10b). The outputs suggest the $\mathrm{Cu}(\mathrm{II})$ compound has a greater ability to cleave DNA with oxidising agent owing to the reaction of $\mathrm{OH}$ radicals with DNA. These hydroxyl free radicals contribute to the oxidation of the deoxyribose moiety and thereby cleavage of $\mathrm{OH}$ group in sugar phosphate backbone [52].

\section{Anti-bactericidal/fungicidal activity}

The antimicrobial function is defined as the path to destroy or prohibit the disease that causes pathogenesis. In this research, the synthesized compounds are scrutinized for their anti-pathogenic action against the selected microbes by micro-dilution method. The synthesized compounds can get quarrelled against pathogens via biochemical and morphological modifications. The antibacterial and antifungal actions of the synthesized compounds are represented in Figs. 11 and 12 and enlisted in Tables 3 and 4. The capability of action was measured by calculating MIC values. Typically, a lower MIC value signifies that smaller amount of the drug is required to inhibit the growth of the organism. In this research, complexes have lower MIC score and so they are more effective antimicrobial agents than ligand.

The augmentation of antimicrobial action of the synthesized complexes was also mentioned by Tweedy's chelation theory. As per the theory, the polarization of the metal ion is reduced to a greater extent, which causes the overlapping of ligand orbital and partial contribution of the metal ion and it magnifies the relocation of the $\pi$-electron inside the chelate ring and boosting the perforation of the compounds into the lipid cell wall. Further, this process locked the metal binding sites in the enzymes of pathogens and thus to divert the breathing process of the cell and thus to obstruct the synthesis of proteins thereby control the augmentation of the microbes [53, 54]. The outputs exemplify that the metal complexes holding $\mathrm{N}$ and $\mathrm{O}$ atoms upon chelation magnify the lipophilicity character and thereby the prohibition of microbes to enter into the living organism. The outputs confirmed metal complexes have more anti-pathogenic skill compared to the free ligand owing to the presence of transition metals, heterocyclic atoms $(\mathrm{N}, \mathrm{O})$, chelation and additional $\pi$-electrons in coordination compounds.

Table 4 Minimum inhibitory concentration of the synthesized free ligand and metal complexes against the growth of fungi $(\mu \mathrm{M})$

\begin{tabular}{llllll}
\hline Compound & \multicolumn{2}{l}{ MIC values $\left(\times 10^{4} \mu \mathrm{M}\right) \mathrm{SEM}= \pm 1.3$} & & \\
\cline { 2 - 6 } & Aspergillus niger & Aspergillus flavus & Curvularia lunata & Rhizoctonia bataticola & Candida albicans \\
\hline Ligand & 23.2 & 25.4 & 22.5 & 21.6 & 22.3 \\
$\mathrm{Cu}(\mathrm{II})$ & 12.2 & 12.3 & 12.7 & 13.8 & 14.5 \\
$\mathrm{Co}(\mathrm{II})$ & 12.8 & 13.2 & 13.4 & 14.8 & 13.2 \\
$\mathrm{Ni}(\mathrm{II})$ & 13.3 & 13.8 & 13.5 & 15.2 & 15.2 \\
Zn(II) & 13.5 & 13.2 & 14.5 & 5.9 & 15.5 \\
Nystatin & 5.8 & 5.2 & 5.6 & 6.1 \\
\hline
\end{tabular}


Table 5 The cytotoxic activity of the synthesized compounds $\mathrm{L}, \mathrm{Cu}(\mathrm{II})$, $\mathrm{Co}(\mathrm{II}), \mathrm{Ni}(\mathrm{II}), \mathrm{Zn}(\mathrm{II}))$ against various human cell lines

\begin{tabular}{llll}
\hline Compound & \multicolumn{2}{l}{$\mathrm{IC}_{50}$ values $(\mu \mathrm{M})$} \\
\cline { 2 - 4 } & MCF-7 & HepG 2 & $\begin{array}{l}\text { HBL- } \\
100\end{array}$ \\
\hline Ligand & $31 \pm 0.5$ & $34 \pm 0.7$ & $96 \pm 0.4$ \\
$\mathrm{Cu}(\mathrm{II})$ & $20 \pm 0.8$ & $18 \pm 0.8$ & $78 \pm 0.8$ \\
$\mathrm{Co}(\mathrm{II})$ & $22 \pm 1.1$ & $21 \pm 1.2$ & $80 \pm 1.0$ \\
$\mathrm{Ni}(\mathrm{II})$ & $24 \pm 0.5$ & $22 \pm 1.2$ & $82 \pm 0.5$ \\
Zn(II) & $25 \pm 0.8$ & $23 \pm 0.8$ & $87 \pm 0.8$ \\
Cisplatin (Standard) & $25 \pm 1.2$ & $20 \pm 1.2$ & $86 \pm 1.1$ \\
\hline
\end{tabular}

\section{In vitro anticancer activity}

Chemotherapy is defined as the utilization of anticancer drugs to slow or prevent the unwanted cell growth of hastily splitting tumour tissues in the body. The encouraging results acquired from the previous DNA binding and cleavage studies encouraged us to evaluate the in vitro cytotoxic activity of synthesized compounds. The compounds are analysed for their antitumor activity against three dissimilar cell lines such as human breast cancer cell line (MCF-7), human liver cancer cell line (Hep G2) and non-cancer cell line from human breast milk (HBL-100) by MTT assay, and cisplatin acts as a standard for this experiment.

The experiment dependent upon the living cells are converted to yellow MTT except for the non-living cells, which tend to display the blue formazan products. Hence, the metabolic actions of the cells are assessed by the ability to split the tetrazolium rings of yellow MTT, which create the blue formazan crystals.

Fig. 13 The cytotoxic studies of the synthesized compounds with breast adenocarcinoma (MCF-7), human liver cancer (Hep G2) and non-cancerous cell lines such as HBL-100 by MTT assay
The aforementioned cell lines are treated with the synthesized compounds and the outcomes of cell hindrance mentioned as $\mathrm{IC}_{50}$ values. All the synthesized metal chelates explain good anticancer activities with low $\mathrm{IC}_{50}$ rate (Table 5; Fig. 13), which implies that the cell activity depends on the concentration of the test solution. $\mathrm{The}^{\mathrm{IC}_{50}}$ values reduce with raising the concentration of metal complexes representing the cytotoxic effect of the prepared compounds based on dosage and period [55]. All the metal complexes show excellent action towards the cancer cell lines because of chelation. At the time of coordination, the metal ion has a positive charge, which enhanced the acidity of the chelating ligand that accepts protons [56]. The cytotoxic potential of the complexes might be associated with the extended planar structure instigated by $\pi \rightarrow \pi^{*}$ conjugation ensuring the coordination of metal ion with the Schiff base. Further, it minimizes their polarization ability through the charge equilibration, which induces the diffusion of the compounds via the lipid layer based on Tweedy's chelation theory [57]. This considerable enhancement in the cytotoxic skill of the complexes than the Schiff base ascertains the coordination. Further, it is described that the transition metal acts as an exclusive role in the anticancer ability of the compounds [58]. Among the synthesized compounds, $\mathrm{Cu}(\mathrm{II})$ complex displays greater anticancer effect because of size, ionic radius, charge on the metal ion, steric factor and pharmaceutical parameters, which act as a vital position in the efficiency of the biological bustle.

\section{Apoptosis study}

Apoptosis is a procedure of modified cell demise that happens in multi-cellular living things. It is a highly controlled process and distinguished via the number of morphological and

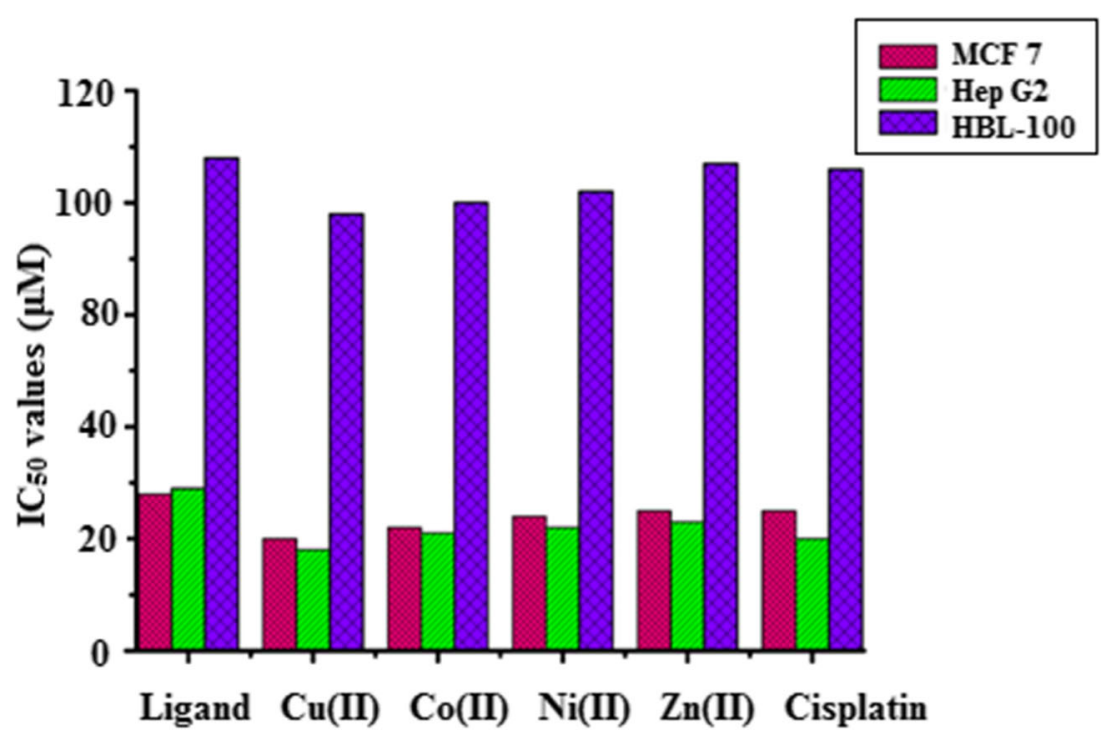

Compounds 
Fig. 14 Hoechst 33258 staining of Hep G2 cells with synthesized complexes, where 1 control, 2 $\mathrm{Cu}(\mathrm{II}), 3 \mathrm{Co}(\mathrm{II}), 4 \mathrm{Ni}(\mathrm{II}), 5 \mathrm{Zn}(\mathrm{II})$

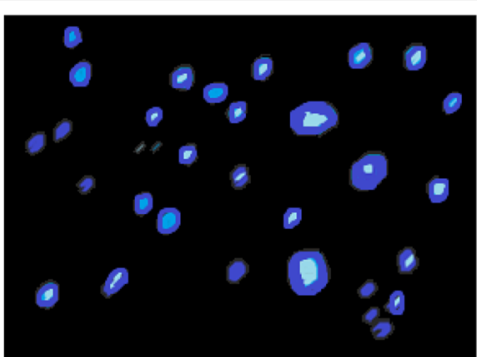

Control

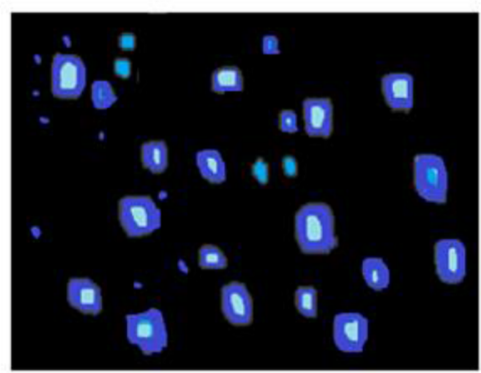

$\operatorname{Co}(I I)$

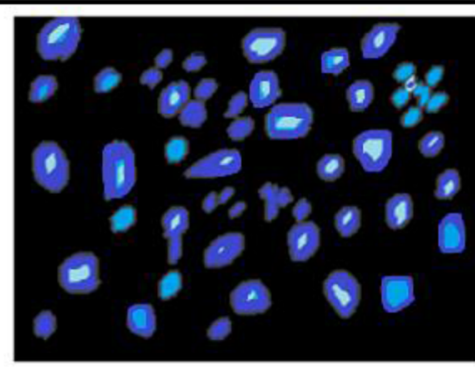

$\mathrm{Cu}(\mathrm{II})$

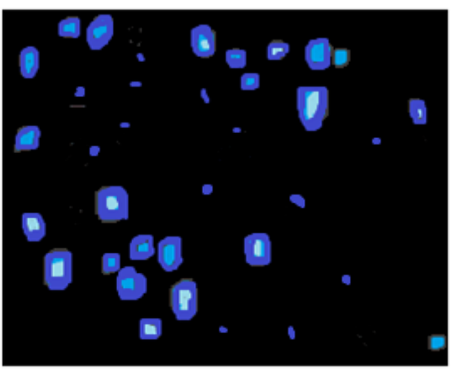

$\mathrm{Ni}(\mathrm{II})$

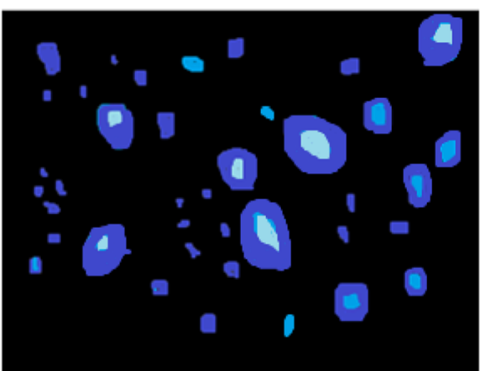

Zn(II)

biochemical characteristic features. Apoptosis can be induced by employing two schemes. In the first scheme, the cell destroys itself since it feels cell strain, whereas, in the extrinsic process, the cell kills solely because of signals from neighbourhood cells and apoptotic bodies lead to cell death, which is confirmed by disparity in cellular functions such as inhibition of cell replication, cytoplasmic reduction and loss of membrane construction [59]. In the current analysis, the metal
Fig. 15 Percentage of antioxidant activity of the Schiff base ligand and its metal complexes using vitamin $\mathrm{C}$ as standard

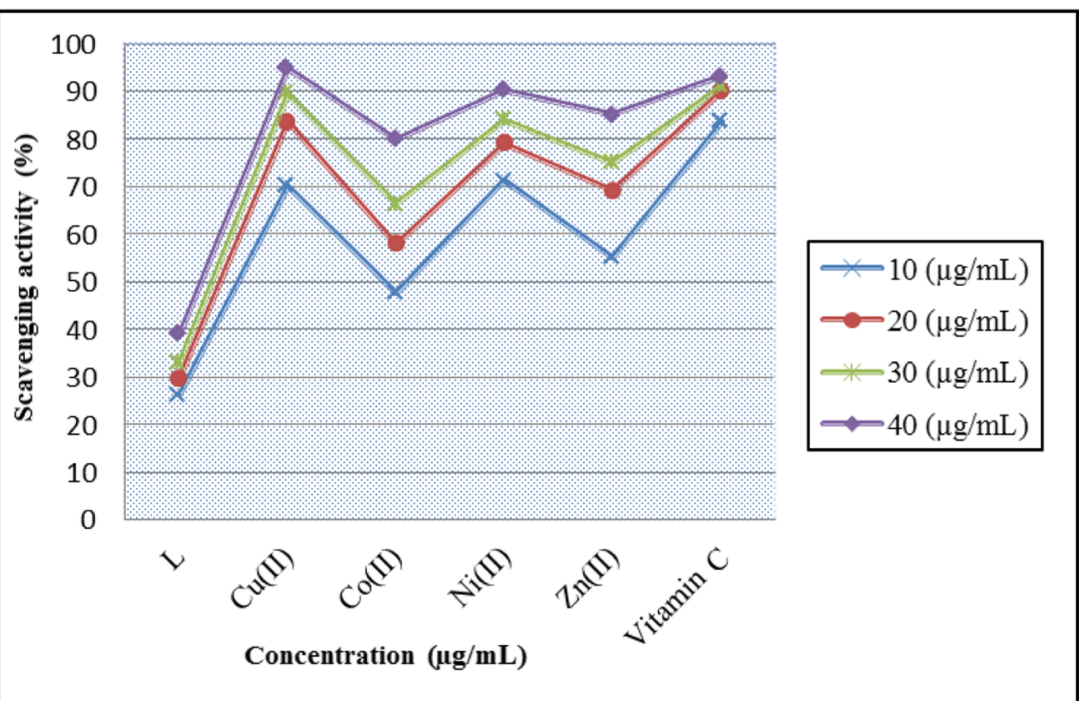


complexes treated with cancer cell lines display some structural variations. During apoptosis, the modification of the cell organelles initiates the cell fatality. The apoptosis results are shown in Fig. 14.

\section{Radical scavenging studies}

Free radicals are produced under definite environmental conditions upon natural metabolic processes. The antioxidant is a vital role in protecting the human body against damage by reactive oxygen species. The formation of hydroxyl radical is the reason for cell damaging and disrupts the natural metabolic process. So, the abolition of this $\mathrm{OH}$ radical is considered as the main goal of introducing the effective antioxidant [60]. The experiment is carried out by DPPH assay by ascorbic acid (vitamin C) as standard.

The reports signify that the metal compounds have greater scavenging skill due to chelation than free Schiff base. Besides, the antioxidant activity of the metal complexes expands the skill, which may lead to save the living organism against several diseases. The antioxidant action of the synthesized compounds is specified in Fig. 15 and enlisted in Table 6.

\section{Computational studies}

\section{Biological activity prognostication}

PASS Online prognosticates over 4000 kinds of biological activity, including pharmacological effects, mechanisms of action, toxic and adverse effects, interaction with metabolic enzymes and transporters, influence on gene expression, etc.

PASS software is employed to discover the pharmacological active organic compounds. The SMILEYs mode of the structure of Schiff base ligand was introduced in the online software. The result signified that Schiff base ligand holds an excellent biological bustle, which acts as an effective antiinflammatory, insulin inhibitor, antineoplastic activity and cancer proagulant inhibitor. It also has efficient ovulation

Table 6 Percentage of antioxidant activity of the Schiff base ligand and its metal complexes

\begin{tabular}{lllllll}
\hline $\begin{array}{l}\text { Concentration } \\
(\mu \mathrm{g} / \mathrm{mL})\end{array}$ & Ligand & $\mathrm{Cu}(\mathrm{II})$ & $\mathrm{Co}(\mathrm{II})$ & $\mathrm{Ni}(\mathrm{II})$ & $\mathrm{Zn}(\mathrm{II})$ & Vitamin C \\
\hline 10 & 26.40 & 70.2 & 47.69 & 71.26 & 55.13 & 83.73 \\
20 & 29.79 & 83.65 & 57.88 & 79.17 & 69.17 & 90.07 \\
30 & 33.15 & 89.67 & 66.35 & 84.13 & 75.12 & 91.15 \\
40 & 39.19 & 94.92 & 80.14 & 90.17 & 85.15 & 95.13 \\
\hline
\end{tabular}

$\%$ of Radical scavanging ability $=\frac{\text { Abs.control-Abs.sample }}{\text { Abs.control }}$ inhibitor, antiulcerative, apoptosis antagonist and free radical scavenging ability. The biological activity assessment of Schiff base ligand is represented in Tables 7 .

\section{In silico ADME-Tox property prediction}

Computational simulation studies furnish a low-cost and rapid approach to determine the drug-like character of synthesized compounds. SwissADME software was used to measure their bioactive score value of the prepared compounds, and toxicity parameters are calculated from AdmetSAR software. It was measured by estimating the different parameters Mi log P

Table 7 Biological activity assessment of Schiff base ligand using PASS online software

\begin{tabular}{lll}
\hline $\mathrm{Pa}$ & $\mathrm{Pi}$ & Activity \\
\hline 0,984 & 0,002 & Anti-inflammatory, intestinal \\
0,487 & 0,054 & Insulin inhibitor \\
0,504 & 0,072 & Mucositis treatment \\
0,476 & 0,081 & Gastrin inhibitor \\
0,463 & 0,079 & Ovulation inhibitor \\
0,353 & 0,043 & Chloride channel blocker \\
0,410 & 0,101 & Antiviral (Picornavirus) \\
0,331 & 0,023 & Antidote \\
0,347 & 0,042 & Urokinase inhibitor \\
0,379 & 0,075 & Insulin promoter \\
0,398 & 0,094 & Neurotransmitter antagonist \\
0,375 & 0,071 & Diabetic neuropathy treatment \\
0,341 & 0,060 & Antiviral (Adenovirus) \\
0,290 & 0,034 & Antiprotozoal (Trichomonas) \\
0,150 & 0,057 & Cancer procoagulant inhibitor \\
0,145 & 0,065 & Antibacterial, ophthalmic \\
0,138 & 0,058 & Urolithiasis treatment \\
0,237 & 0,158 & Antiulcerative \\
0,185 & 0,132 & Antialcoholic \\
0,126 & 0,073 & Antithyroid \\
0,189 & 0,141 & Apoptosis antagonist \\
0,162 & 0,114 & Free radical scavenger \\
0,051 & 0,017 & Neuropathy treatment \\
0,153 & 0,123 & Choleretic \\
0,140 & 0,110 & Antineoplastic (glioma) \\
0,164 & 0,136 & Severe acute respiratory syndrome treatment \\
0,106 & 0,080 & Neuropsin inhibitor \\
0,158 & 0,131 & Antineoplastic (glioblastoma multiforme) \\
0,042 & 0,032 & Antiviral (Parainfluenza) \\
0,111 & 0,101 & Acrosin inhibitor \\
0,026 & 0,018 & Mental retardation treatment \\
- & - & - \\
\hline$P a$ & & \\
\hline
\end{tabular}

$P a$ probability of active, $P i$ probability of inactive 
Table 8 Prediction of in silico ADMET properties of the Schiff base ligand and metal complexes

\begin{tabular}{|c|c|c|c|c|c|c|c|c|c|}
\hline \multirow[t]{2}{*}{ Compounds } & \multirow{2}{*}{$\begin{array}{l}\text { Molecular } \\
\text { formula }\end{array}$} & \multirow{2}{*}{$\begin{array}{l}\text { Molecular } \\
\text { weight }(\mathrm{g} / \mathrm{mol})\end{array}$} & \multicolumn{5}{|c|}{ Physicochemical parameters } & \multirow{2}{*}{$\begin{array}{l}\text { Bioactivity } \\
\text { score }\end{array}$} & \multirow{2}{*}{$\begin{array}{l}\text { Toxicity parameters } \\
\text { Carcinogenic } \\
\text { activity/mutagenic } \\
\text { Activity/Irritant }\end{array}$} \\
\hline & & & $\begin{array}{l}\log \\
\mathrm{P}\end{array}$ & $\begin{array}{l}\text { TPSA } \\
\left(\AA^{2}\right)\end{array}$ & $\begin{array}{l}\text { No. of } \mathrm{H} \text { bond } \\
\text { acceptor }\end{array}$ & $\begin{array}{l}\text { No. of } \mathrm{H} \\
\text { bond donor }\end{array}$ & $\begin{array}{l}\text { No. of } \\
\text { rotatable } \\
\text { bonds }\end{array}$ & & \\
\hline Ligand & $\mathrm{C}_{24} \mathrm{H}_{18} \mathrm{~N}_{4} \mathrm{O}_{2}$ & 394 & 3.07 & 90.96 & 6 & 2 & 5 & 0.85 & none \\
\hline $\mathrm{Cu}(\mathrm{II})$ & $\mathrm{C}_{24} \mathrm{H}_{16} \mathrm{CuN}_{4} \mathrm{O}_{2}$ & 455 & 0.00 & 68.96 & 6 & 0 & 2 & 0.55 & none \\
\hline $\mathrm{Co}(\mathrm{II})$ & $\mathrm{C}_{24} \mathrm{H}_{16} \mathrm{CoN}_{4} \mathrm{O}_{2}$ & 451 & 0.00 & 68.96 & 6 & 0 & 2 & 0.55 & none \\
\hline $\mathrm{Ni}(\mathrm{II})$ & $\mathrm{C}_{24} \mathrm{H}_{16} \mathrm{NiN}_{4} \mathrm{O}_{2}$ & 451 & 0.00 & 68.96 & 6 & 0 & 2 & 0.55 & none \\
\hline $\mathrm{Zn}(\mathrm{II})$ & $\mathrm{C}_{24} \mathrm{H}_{16} \mathrm{ZnN}_{4} \mathrm{O}_{2}$ & 457 & 0.00 & 68.96 & 6 & 0 & 6 & 0.55 & none \\
\hline
\end{tabular}

(partition coefficient), compound weight, heavy atoms, hydrogen donors, hydrogen acceptors and rotatable bonds Table 8.

In silico ADMET includes the property of absorption, distribution, metabolism excretion and toxicity which is utilized to predict the drug-likeness behaviour of the compounds based on Lipinski's rule of five [61]. This rule stated that $\log P$ values of compounds should have below 5, molecular weight lower than 500, H-bond acceptors should be smaller than 10, H-bond donors should be lower than 5 and should have smaller than one bioactive score.

Log P It is a parameter to determine the hydrophobic character of the synthesized compound, which is necessary for analyzing permeability skill of the compounds across the cell membrane. In the present study, Mi log $P$ values for synthesized ligand and complexes are found less than 5; it signifies that the compounds
Fig. 16 The binding model of synthesized compounds with

Bowmann-Birk receptor

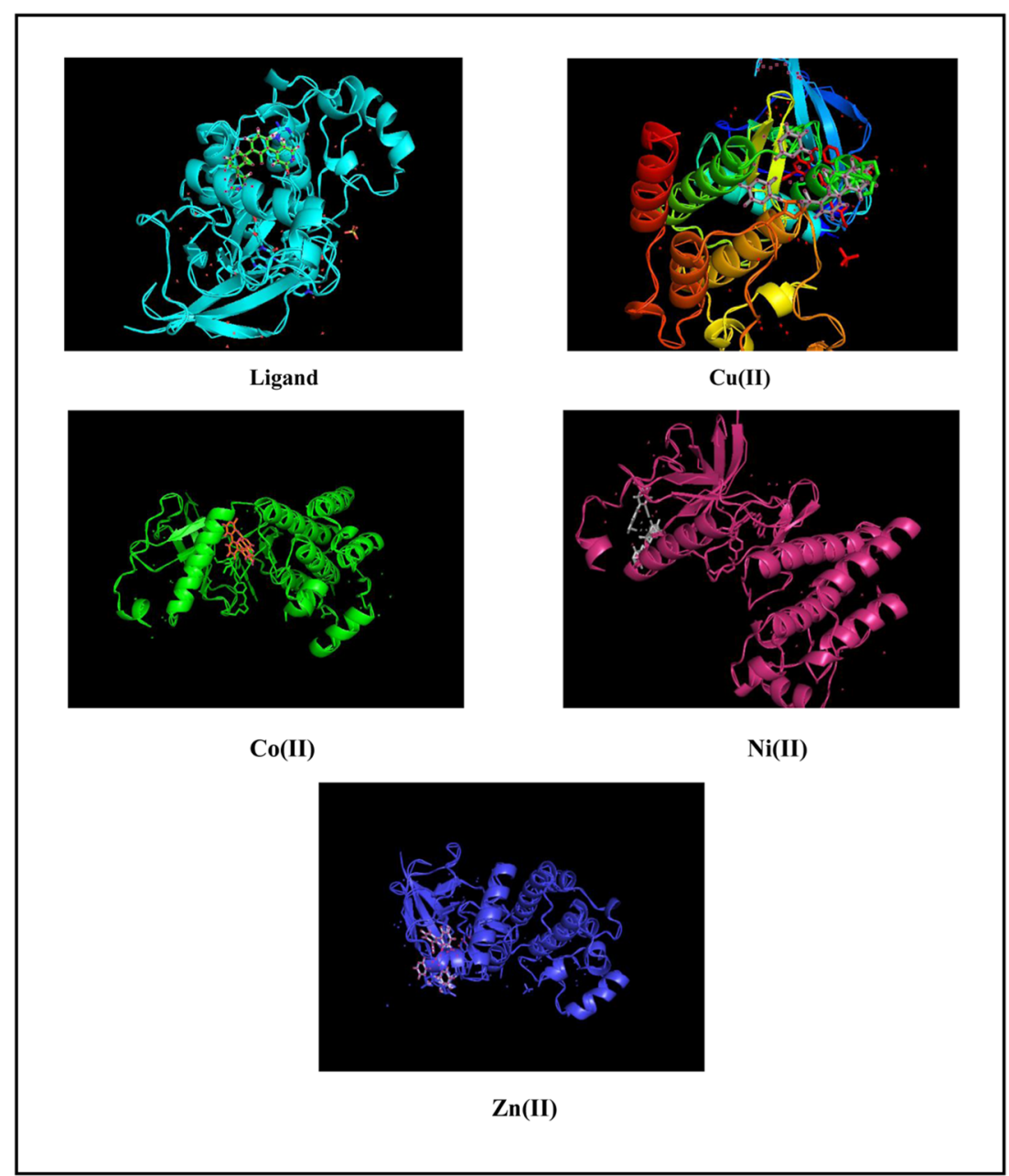


should have appreciable penetrable talent across the central nervous system.

Molecular weight The molecular weight of the synthesized compounds is less than 500. As per Lipinski regulation, the compounds have good drug-likeness criterion.

H-releasing and withdrawing capacity In the current research, the counting of hydrogen donors is two and the number of the hydrogen acceptors is five which have been noticed for Schiff base ligand. But metal complexes have six hydrogen bond acceptors and no hydrogen bond donors. Based on this rule, the compounds possess many $\mathrm{H}$-donor and acceptors, and the particular compounds act stretchier and interact with active sites effectively.

Topological molecular polar surface area It is a commonly analyzed factor related to $\mathrm{H}$-bonding ( $\mathrm{O}$ and $\mathrm{N}$ atom counts) that is necessary to identify the cell permeability phenomena. Topological molecular polar surface area (TPSA) is calculated by addition of $\mathrm{O}, \mathrm{N}$ and attached $\mathrm{H}$ in synthesized compounds.
It is a significant parameter that was compared with the passive diffusion through the cell wall; hence, it agreed to pass the drug candidates inside the central nervous system. In this research, ligand acquires TPSA value $90.96 \AA^{2}$ (below $140 \AA^{2}$ ) and complexes have $68.96 \AA^{2}$, which explain the synthesized compounds possess good drug transport features and may be favoured for oral administration.

Rotatable bonds As per Lipinski's rule, while the rotatable bond increases, the molecules become more stretchy and convenient for interface with the accurate active centre. The counting of this parameter for synthesized ligand and metal chelates are five and two respectively. In the current investigation, the data evidently designated that the synthesized compounds have suited talent to interact with the living cells efficiently.

Bioactivity score prediction The drug activity of the compound describes the optimistic effects of drugs on living organisms. The drug should be implanted with a natural entity including proteins, enzymes, ion channels and receptors. The
Fig. 17 The binding model of synthesized compounds with DNA

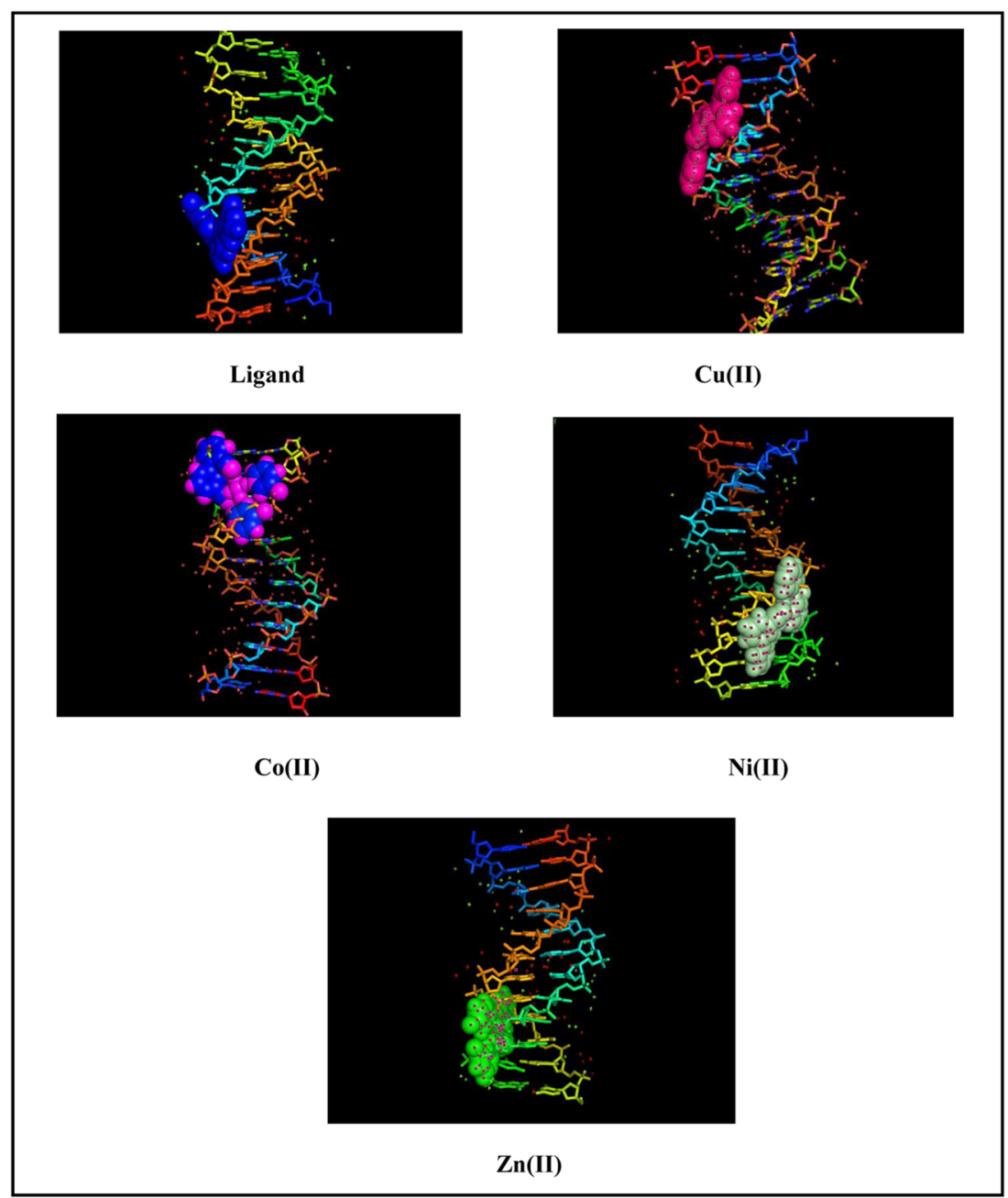


bioactivity score of the drug can be scrutinized by measuring the activity score of GPCR ligand, ion channel modulator, nuclear receptor ligand, kinase inhibitor, protease inhibitor and enzyme inhibitor. For this analysis, ligand and the metal chelates have bioactivity scores 0 and 0.5 respectively. As per the Lipinski's rule, the compounds which possess bioactivity scores greater than 0 are the compounds have excellent druglikeness proficiency [62]. This output has coincided the same.

Toxicity assessment Mutagenic and carcinogenic activities were calculated by AdmetSAR software. Assessment of toxicity parameter is the main factor for the invention of novelbased therapeutic drugs. From the theoretical results, synthesized compounds have no toxicity risk.

\section{Molecular docking}

Molecular docking is utilized to ensure the mode of interaction of DNA with prepared compounds [63, 64]. In this research, the docking study is performed by AutoDock Vina software against the protein Bowman-Birk inhibitor (PDB ID:1D6R) attached in Fig. 16. 1D6R inhibitor naturally presents in soya beans, leguminous plants and some cereal grains. This is a protease inhibitor, and it is capable of preventing the proliferation of cancer cells. Because the tumour tissues are more reactive than ordinary tissues, the prevention of proteasome inhibitor is considered a significant task in cancer therapy. From these simulation studies, the obtained interaction energy of synthesized compounds are -228.83 (L), -244.74 $\mathrm{Cu}(\mathrm{II}),-233.07 \mathrm{Co}(\mathrm{II}),-232.92 \mathrm{Ni}(\mathrm{II}))$ and $-232.83 \mathrm{~kJ} / \mathrm{mol}$ $\mathrm{Zn}(\mathrm{II})$. It is concluded that the compound, which has a high level of negative energy value, and the compound should have a better binding relationship. The current docking study denotes that metal complexes have a high bound gravity with protein rather than free ligand.

The interaction of synthesized compounds with nucleic acid was performed by the aforementioned software using receptor DNA (PDB ID: 1BNA). The interaction potential of synthesized compounds with nucleic acid is -210.44 (L), $-236.57 \mathrm{Cu}$ (II), $214.68 \mathrm{Co}(\mathrm{II}),-212.66 \mathrm{Ni}$ (II) and $-210.60 \mathrm{Zn}$ (II) $\mathrm{kJ} / \mathrm{mol}$. The result (Fig. 17) indicates that the synthesized compounds were penchant with DNA base pairs through intercalative mode involving the external way of intercommunication with sugarphosphate linkage of the nucleic acid [65]. Docking reports have good agreement with DNA-binding experimental reports which confirmed the intercalative pathway between nucleic acid and synthesized compounds [66].

\section{Conclusion}

In this research novel, bio-crucial pyridine-derived Schiff base ligand and four metal complexes were synthesized and characterized. From all the spectral result, copper complex adopts square planar geometry, but cobalt, nickel and zinc complexes have tetrahedral geometry. The DNA binding result confirmed that the synthesized compound interplay with deoxyribonucleic acid by intercalative mode and the mode of interaction is further confirmed by molecular docking simulations. The gel electrophoresis reports enunciated that the copper complex has greater tendency to divide the DNA double strand with activator. The output of antimicrobial activity displays that the metal complexes possess an excellent antipathogenic skill rather than ligand. Moreover, the reports of anticancer activity revealed that the synthesized complexes display the appreciable anticancer activity and subsequent cell death occurs during apoptosis. The antioxidant reports enunciated that synthesized complexes have greater antioxidant skill than ligand due to chelation. The prediction of in silico ADMET property found out that metal complexes possess admirable "drug-like" property according to Lipinski's regulations. Consequently, from all the biological reports, it is concluded that the synthesized compounds may be blooming into an efficient malignant tumour and antimicrobial medication after following some advance therapeutic approaches in future research.

Acknowledgements The author, S.SAF, gratefully acknowledges the International Research Centre, Kalasalingam Academy of Research and Education for offering research fellowship and necessary facilities.

\section{Compliance with ethical standards}

Conflict of interest The authors declare that they have no conflict of interest.

\section{References}

1. Magner LN (2005) A history of medicine. Taylor \& Francis Group, LLC, Boca Raton, pp 1-624

2. Thompson KH (2011) Encyclopaedia of inorganic chemistry. John Wiley \& Sons Ltd, Chichester

3. Orvig C, Abrams MJ (1999) Medicinal inorganic chemistry: introduction. Chem Rev 99:2201-2204

4. Hossain MS, Roy PK, Ali R, Zakaria CM, Kudrat M, Zahan E (2017) Selected pharmacological application of I row transition metal complexes: a review. Clin Med Res 6:177-191

5. Raman N, Syed Ali Fathima S, Dhaveethu Raja J (2008) Designing, synthesis and spectral characterization of Schiff base transition metal complexes: DNA cleavage and antimicrobial activity studies. J Serb Chem Soc 73:1063-1071

6. Al Zoubi W, Ali Salih Al-Hamdani A, Ahmed SD, Gun Ko Y (2017) A new azo-Schiff base: synthesis, characterization, biological activity and theoretical studies of its complexes. Appl Organomet Chem 6:3895-3907

7. Hossain MS, Zakaria CM, Haque MM, Zahan MK-E (2016) Spectral and thermal characterization with antimicrobial activity on $\mathrm{Cr}(\mathrm{III})$ and $\mathrm{Sn}(\mathrm{II})$ complexes containing N, O donor novel Schiff base ligand. J Chem Biol Phys Sci 6:41-52 
8. Naik AD, Annigeri SM, Gangadharmath UB, Revankar VK, Mahale VB (2002) Anchoring mercapto-triazoles on dicarbonyl backbone to assemble novel bi- nucleating, acyclic SNONS compartmental ligands. Indian J Chem 41A:2046-2053

9. Casas KGO, Oliveira MLG, Fatima Silva GD, Viasus CJ, Burgos AE (2015) Synthesis of cu(II) complex with schiff bases derived from aryl-S-benzyildithiocarbazate: antimicrobial activity and in silico biological properties evaluations. Afr J Phar Pharmaco 9: 1009-1019

10. Sharma MC, Shahu NK, Kohli DV, Chaturvedi SC (2009) Synthesis, characterization and biological activities of some 1(nicotinylamino) -2-substituted azetidine-4-ones as potential antibacterial agents. Dig J Nanomater Biostruct:4361-4367

11. Timmins GS, Master S, Rusnak F, Deretic V (2004) Nitric oxide generated from isoniazid activation by KatG: source of nitric oxide and activity against mycobacterium tuberculosis. Anti Microb Agents Chemother 48:3006-3009

12. Shavit M, Tshuva EY (2008) Preparation and X-ray structures of Ti(IV) complexes of bis(carboxylato) ligands-formation of mono, $\mathrm{di}$, tetra, and hexanuclear complexes with or without $\mathrm{OR}$ and $\mu-\mathrm{O}$ ligands. Eur J Inorg Chem 14:1467-1474

13. Dubois L, Pecaut J, Charlot MF, Baffert C, Collomb MN, Deronzier A, Latour JM (2008) Drastically enhance the rates of oxo exchange and hydrogen peroxide disproportionation by oxo manganese compounds of potential biological significance. Chem Eur J 14:30133025

14. Zhao M, Helms B, Slonkina E, Friedle S, Lee D, DuBois J, Hedman B, Hodgson KO, Frechet JM, Lippard SJ (2008) Iron complexes of dendrimer-appended carboxylates for activating dioxygen and oxidizing hydrocarbons. J Am Chem Soc 130:4352-4363

15. Yang CI, Wernsdorfer W, Tsai YJ, Chung G, Kuo TS, Lee GH, Shieh M, Tsai HL (2008) Mixed-valence tetra and hexanuclear manganese complexes from the flexibility of pyridine-containing $\beta$-diketone ligands. Inorg Chem 47:1925-1939

16. Vasconcellos-Dias M, Nunes CD, Vaz PD, Ferreira P, Calhorda MJ (2007) Pyridine carboxylate complexes of Mo(II) as active catalysts in homogeneous and heterogeneous polymerization. Eur J Inorg Chem 18:2917-2925

17. Jong-Keun S, Long-Xuan Z, Arjun B, Pritam T, Radha K, Younghwa N, Yurngdong J, Tae Cheon J, Byeong-Seon J, Chong-Soon L, Eung Seok L (2008) Synthesis of 2,6-diarylsubstituted pyridines and their antitumor activities. Eur J Med Chem 43:675-682

18. Garcia-Friaza G, Fernandez-Betello A, Perez JM, Prieto MJ, Moreno V (2006) Synthesis and characterization of palladium(II) and platinum(II) complexes with Schiff bases derivatives of 2pyridincarboxyaldehyde:study of their interaction with DNA. J Inorg Biochem 100:1368-1377

19. Lee Arnold D, Viswanatha T (1983) The use of bis(mercaptoacetato-S,O) hydroiron (III) complex for the determination of hydrooxamates. J Biochem Biophys Methods 8:307-320

20. Banerjea D (1998) Coordination chemistry. Tata McGraw-Hill Pub, New Delhi

21. Chohan ZH, Arif M, Sarfraz M (2007) Synthesis, characterization, luminescent properties and biological activities of zinc complexes with bidentate azomethine Schiff-base ligands. Appl Organomet Chem 21:294-305

22. Lever ABP (1984) Studies in physical and theoretical chemistry. Inorganic Electronic Spectroscopy. Elsevier, Amsterdam, p 33

23. Cotton FA, Wilkinson G (1998) Advanced inorganic chemistry. Wiley-Interscience, New York, pp 1-1376

24. Day MC, Selbin J (1969) Theoretical inorganic chemistry. Litton Edu Pub Inc

25. Temel H, Ilhan S, Sekerci M, Ziyadanogullari R (2002) The synthesis and spectral characterization of new $\mathrm{Cu}(\mathrm{II}), \mathrm{Ni}(\mathrm{II}), \mathrm{Co}(\mathrm{III})$, and Zn(II) complexes with Schiff base. Spectrosc Lett 35:219-228
26. Sobha S, Mahalakshmi R, Raman N (2012) Studies on DNA binding behaviour of biologically active transition metal complexes of new tetradentate $\mathrm{N}_{2} \mathrm{O}_{2}$ donor Schiff bases: inhibitory activity against bacteria. Spectrochim Acta A 92:175-183

27. Patil M, Hunoor R, Gudasi K (2010) Transition metal complexes of 3-aryl-2-substituted 1, 2-dihydroquinazolin-4 (3H)-one derivatives: new class of analgesic and anti-inflammatory agents. Eur J Med Chem 45:2277-2282

28. Vijayalakshmi R, Kanthimathi M, Parthasarathi R, Nair BU (2006) Interaction of chromium(III) complex of chiral binaphthyl tetradentate ligand with DNA. Bioorg Med Chem 14:3300-3306

29. Ray RK, Kauffman GB (1990) EPR spectra and covalency of bis(amidinourea/O alkyl-1-amidinourea)copper(II)complexes part II: properties of the $\mathrm{CuN}_{4}{ }^{2-}$ chromophore. Inorg Chim Acta 173: 207-214

30. Srinivasan S, Athappan P, Rajagopal G (2001) Synthesis, spectral and redox properties of metal complexes of macrocyclic tetraaza chiral Schiff bases. Transit Met Chem 26:588-593

31. Hathaway BJ, Billing DE (1970) The electronic properties and stereochemistry of mononuclear complexes of the copper(II) ion. Coord Chem Rev 5:143-207

32. Dudley RJ, Hathaway BJ (1970) Single-crystal electronic and electron spin resonance spectra of 2,2' bipyridylbis(hexafluoroacetylacetonato)copper(II). J Chem Soc A 0:2794-2799

33. Kurdekar GS, Sathisha MP, Budagump S, Kulkarni NV, Revankar VK, Suresh DK (2012) 4-Aminenoantipyrine-based Schiff-base transition metal complexes as potent anticonvulsant agents. Med Chem Res 21:2273-2279

34. Dhanaraj CJ, Nair MS (2009) Synthesis, characterization and antimicrobial studies of some Schiff base metal(II) complexes. J Coord Chem 62:4018-4028

35. Dhanaraj CJ, Nair MS (2009) Synthesis and characterization of metal(II) complexes of poly-3nitro benzylidine-1-naphthylamineco-succinican hydride. Eur Polym J 45:565-572

36. Syed Ali Fathima S, Mohamed Sahul Meeran M, Nagarajan ER (2019) Synthesis of novel (E)-2-( (anthracen-9ylmethylene)amino)pyridin-3-ol and its transition metal complexes: multispectral characterization, biological evaluation and computational studies. J Mol Liq 279:177-118

37. Kumar A, Chinta JP, Ajay AK, Bhat MK, Rao CP (2011) Synthesis, characterization, plasmid cleavage and cytotoxicity of cancer cells by a copper(II) complex of anthracenyl terpyridine. Dalton Trans 40:10865-10872

38. Khan TA, Naseem S, Khan SN, Khan AU, Shakir M (2009) Synthesis and spectral characterization of 14- and 16-membered tetra azamacrocyclic Schiff base ligands and their transition metal complexes and a comparative study of interaction of calf thymus DNA with copper(II) complexes. Spectrochim Acta A 73:622-629

39. Barton JK, Danishefsky A, Goldberg J (1984) Tris(phenanthroline)ruthenium(II): Stereoselectivity in binding to DNA. J Am Chem Soc 106:2172-2176

40. Friedman AE, Kumar CV, Turro NJ, Barton JK (1991) Luminescence of ruthenium(II) polypyridyls: evidence for intercalative binding to Z-DNA. Nucleic Acids Res 19:2595-2602

41. Chauhan M, Banerjee K, Arjmand F (2007) DNA binding studies of novel copper(II) complexes containing l-tryptophan as chiral auxiliary: in vitro antitumor activity of $\mathrm{Cu}-\mathrm{Sn}_{2}$ complex in human neuroblastoma cells. Inorg Chem 46:3072-3082

42. Zhang S, Zhou J (2008) Ternary copper(II) complex of 1,10phenanthroline and L-glycine: crystal structure and interaction with DNA. J Coord Chem 61:2488-2498

43. Liu XW, Li J, Li H, Zheng KC, Chao H, Ji LN (2005) Synthesis, characterization, DNA-binding and photocleavage of complexes $\left[\mathrm{Ru}(\mathrm{phen})_{2}(6-\mathrm{OH}-\mathrm{dppz})\right]^{2+}$ and $\left[\mathrm{Ru}(\mathrm{phen}) 2\left(6-\mathrm{NO}_{2}-\mathrm{dppz}\right)\right]^{2+} . \mathrm{J}$ Inorg Biochem 99:2372-2380 
44. Yang ZS, Wang YL, Zhao GC (2004) The interaction of copperbipyridyl complex with DNA and cleavage to DNA. Anal Sci 20: $1127-1130$

45. Tarui M, Doi M, Ishida Inoue M, Nakaike S, Kitamura K (1994) DNA-binding characterization of a novel anti-tumour benzo[a]phenazine derivative NC-182: spectroscopic and viscometric studies. Biochem J 304:271-279

46. Guo H, Lu J, Ruan Z, Zhang Y, Liu Y, Zang L, Jiang J, Huang J (2014) Synthesis, crystal structures and biological activity of oxovanadium(V) complexes with similar tridentate hydrazone ligands. J Coord Chem 65:1776-1780

47. Liao LB, Zhou HY, Xiao XM (2005) Spectroscopic and viscosity study of doxorubicin interaction with DNA. J Mol Struct 749:108113

48. Satyanarayana S, Dabrowiak JC, Chaires JB (1993) Tris(phenanthroline) ruthenium(II) enantiomer interactions with DNA: mode and specificity of binding. Biochemistry 32:25732584

49. Wittung P, Nielsen P, Norden B (1996) Direct observation of strand invasion by peptide nucleic acid (PNA) into double-stranded DNA. J Am Chem Soc 118:7049-7054

50. Kashanian S, Khodaei M, Pakravan P, Adibi H (2010) Spectroscopic studies on the interaction of isatin with calf thymus DNA. DNA Cell Biol 39:639-646

51. Liu F, Wang K, Bai G, Zhang Y, Gao L (2004) The pH-induced emission switching and interesting DNA-binding properties of a novel dinuclear ruthenium(II) complex. Inorg Chem 43:1799-1806

52. Anjaneyula Y, Rao RP (1986) Preparation, characterization and antimicrobial activity studies on some ternary complexes of $\mathrm{Cu}$ (II) with acetylacetone and various salicylic acids. Synth React Inorg Met 16:257-272

53. Syed Ali Fathima S, Paul Pandiyan R, Nagarajan ER (2018) Expatiating biological excellence of aminoantipyrine derived novel metal complexes: combined DNA interaction, antimicrobial, free radical scavenging studies and molecular docking simulations. J Mol Struct 1178:179-191

54. Gao EJ, Liu TL, Jiao W, Jiang LL, Zhang D, Zhang YJ, Xu J, Wu GL (2013) Crystal structure of a new transition metal-organic Zn(II) complex. J Struct Chem 54:972-977

55. Rosu T, Pahontu E, Pasculescu S, Georgescu R, Stanica N, Curaj A, Popescu A, Leabu M (2010) Synthesis, characterization, antibacterial and antiproliferative activity of novel $\mathrm{Cu}(\mathrm{II})$ and $\mathrm{Pd}(\mathrm{II})$ complexes with 2-hydroxy-8-R-tricyclo[7.3.1.0.(2,7)] tridecane13-one thiosemicarbazone. Eur J Med Chem 45:1627-1634

56. Ramadan AM (1997) Structural and biological aspects of copper (II) complexes with 2-methyl-3-amino-(3H)-quinazolin-4-one. J Inorg Biochem 65:183-189

57. Avaji PG, Kumar CHV, Patil SA, Shivananda KN, Nagaraju C (2009) Synthesis, spectral characterization, in-vitro microbiological evaluation and cytotoxic activities of novel macrocyclic bis hydrazone. Eur J Med Chem 44:3552-3359

58. Krishnamorthy P, Sathyadevi P, Cowlwy AH, Butorac RR, Dharamaraj N (2011) Evaluation of DNA binding, DNA cleavage, protein binding and in vitro cytotoxic activities of bivalent transition metal hydrazone complexes. Eur J Med Chem 46:3376-3387

59. Udilova N, Kozlov AV, Bieberschulte W, Frei K, Ehrenberger K, Nohl H (2003) The antioxidant activity of caroverine. Biochem Pharmacol 65:59-65

60. Lipinski CA, Lombardo F, Dominy BW, Feeney PJ (2001) Experimental and computational approaches to estimate solubility and permeability in drug discovery and development settings. Adv Drug Deliv 46:3-26

61. Lipinski CA (2004) Lead and drug-like compounds: the rule-of-five revolution. Drug Discov Today Technol 1:337-341

62. Lakshmipraba J, Arunachalam S, Solomon RV, Venuvanalingam P, Riyasdeen A, Dhivya R, Akbarsha MA (2015) Surfactantcopper(II) Schiff base complexes: synthesis, structural investigation, DNA interaction, docking studies and cytotoxic activity. J Biomol Struct Dyn 33:877-891

63. Nitiss JL (2009) Targeting DNA topoisomerase II in cancer chemotherapy. Nat Rev Cancer 9:338-350

64. Pommier Y (2006) Topoisomerase I inhibitors: Camptothecins and beyond. Nat Rev Cancer 6:789-802

65. Singh SK, Joshi S, Singh AR, Saxena JK, Pandey DS (2007) DNA binding and topoisomerase II inhibitory activity of water-soluble ruthenium(II) and rhodium(III) complexes. Inorg Chem 46: 10869-10876

66. Liang G, Liu Z, Wu J, Cai Y, Li X (2012) Anticancer molecules targeting fibroblast growth factor receptors. Trends Pharmacol Sci 33:531-541

Publisher's note Springer Nature remains neutral with regard to jurisdictional claims in published maps and institutional affiliations. 